\title{
Consumers' acceptance and preferences for nutrition-modified and functional dairy products: a systematic review
}

Article

Accepted Version

Creative Commons: Attribution-Noncommercial-No Derivative Works 4.0

Bimbo, F., Bonanno, A., Nocella, G., Viscecchia, R., Nardone, G., Devitiis, B. and Carlucci, D. (2017) Consumers' acceptance and preferences for nutrition-modified and functional dairy products: a systematic review. Appetite, 113. pp. 141-154. ISSN 0195-6663 doi:

https://doi.org/10.1016/j.appet.2017.02.031 Available at https://centaur.reading.ac.uk/69300/

It is advisable to refer to the publisher's version if you intend to cite from the work. See Guidance on citing.

To link to this article DOI: http://dx.doi.org/10.1016/j.appet.2017.02.031

Publisher: Elsevier

All outputs in CentAUR are protected by Intellectual Property Rights law, including copyright law. Copyright and IPR is retained by the creators or other copyright holders. Terms and conditions for use of this material are defined in the End User Agreement. 


\section{CentAUR}

Central Archive at the University of Reading

Reading's research outputs online 


\section{Accepted Manuscript}

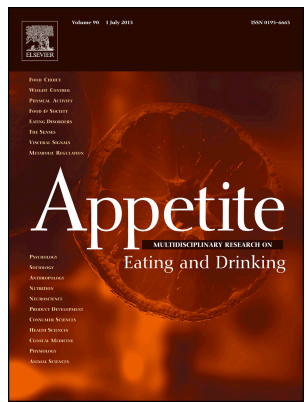

Consumers' acceptance and preferences for nutrition-modified and functional dairy products: A systematic review

Francesco Bimbo, Alessandro Bonanno, Giuseppe Nocella, Rosaria Viscecchia, Gianluca Nardone, Biagia De Devitiis, Domenico Carlucci

PII: S0195-6663(17)30274-X

DOI: 10.1016/j.appet.2017.02.031

Reference: $\quad$ APPET 3349

To appear in: Appetite

Received Date: 4 April 2016

Revised Date: 9 December 2016

Accepted Date: 20 February 2017

Please cite this article as: Bimbo F., Bonanno A., Nocella G., Viscecchia R., Nardone G., De Devitiis B. \& Carlucci D., Consumers' acceptance and preferences for nutrition-modified and functional dairy products: A systematic review, Appetite (2017), doi: 10.1016/j.appet.2017.02.031.

This is a PDF file of an unedited manuscript that has been accepted for publication. As a service to our customers we are providing this early version of the manuscript. The manuscript will undergo copyediting, typesetting, and review of the resulting proof before it is published in its final form. Please note that during the production process errors may be discovered which could affect the content, and all legal disclaimers that apply to the journal pertain. 
1 Consumers' acceptance and preferences for nutrition-modified and

2 functional dairy products: a systematic review.

3

4

Keywords: nutrition-modified and functional dairy products, systematic review, consumers' acceptance and preferences, attitudes, perceived healthiness.

\author{
Abstract
}

This systematic literature review collects and summarizes research on consumer acceptance and preferences for nutrition-modified and functional dairy products, to reconcile, and expand upon, the findings of previous studies. We find that female consumers show high acceptance for some functional dairy products, such as yogurt enriched with calcium, fiber and probiotics. Acceptance for functional dairy products increases among consumers with higher diet/health related knowledge, as well as with aging. General interest in health, food-neophobia and perceived self-efficacy seem also to contribute shaping the acceptance for functional dairy products. Furthermore, products with "natural" matches between carriers and ingredients have the highest level of acceptance among consumers. Last, we find that brand familiarity drives consumers with low interest in health to increase their acceptance and preference for healthenhanced dairy products, such as probiotic yogurts, or those with a general function claim.

\title{
1. Introduction
}

In the last decades consumer demand for health-enhancing food products, such as nutrition-modified (e.g. low-fat products or with fiber added) and functional foods, has grown rapidly. Consumer demand for health-enhancing foods has spurred in part because of socio-economic changes, such as the longer life expectancy, the rise of health care costs, the social costs of non-transmittable diseases, and the widespread desire for a better quality of life (Valls et al., 2013).

A recent report estimates that the global market for foods with health-enhancing features amounted to (approximately) $\$ 168$ billion in 2013, with an annual average 
1 growth rate of $8.5 \%$, and it is forecasted to exceed $\$ 300$ billion by 2020 (Research and

2 Markets, 2014). Food companies, attracted by such market growth and high margins,

3 have been investing in the development of new nutrition-modified and functional

4 products (Khan et al., 2014).

5 However, these market projections mask a high risk of product failure as 70 to 90

6 per cent of new health-enhancing products exit the market within the first two years

7 from their launch (Heasman \& Mellentin, 2001; Stein \& Rodríguez-Cerezo, 2008;

8 Hardy, 2010). One of the likely reasons for such high failure rates is that product

9 development is often driven by technical feasibility (Bleiel, 2010) disregarding

10 consumers' acceptance and preferences (Van Kleef et al., 2002; 2005a). This approach

11 may lead to a mismatch between consumers' needs and the features of new nutrition-

12 modified and functional food products introduced in the market (Van Kleef et al.,

13 2002). In spite of existing research having given great emphasis to consumers

14 acceptance and preferences towards nutrition-modified and functional foods (Van Kleef

15 et al., 2002; Verbeke, 2005; Ares \& Gámbaro, 2007), existing knowledge is

16 fragmented, and the findings from studies conducted in different contexts appear

17 difficult to reconcile. One likely reason for this difficulty may be that so far scholars

18 have focused on only one or just a few aspects of consumer behavior, thus failing to

19 provide an integrated picture of the multiple elements affecting the acceptance and the

20 preferences for these products (Starling, 2014).

21 One approach used to gather relevant knowledge in fields where evidence is

22 fragmented is the systematic review, which selects studies through a multi-step

23 procedure (Cooper, 1998; Littell \& College, 2006), also allowing for an assessment of

24 the studies' quality (Littell et al., 2008). To the best of our knowledge, only two

25 systematic reviews on functional foods exists (Ozen et al., 2012; Ozen et al., 2014). 
1 Ozen et al. (2012) systematically reviewed twenty-three worldwide studies on

2 individual consumption of functional products belonging to different food categories.

3 These authors concluded that it was not possible to clearly identify how gender, age,

4 level of education and socio-economic characteristics influenced the consumption of

5 functional foods. Similarly, Ozen et al. (2014), by systematically reviewing studies on

6 European consumers, failed to identify gender differences in the individual

7 consumption of many categories of nutrition-modified and functional foods; however,

8 these authors pointed out a higher consumption of such products among North

$9 \quad$ European consumers.

10 The contradictory findings highlighted in these systematic reviews may be due to

11 the authors considered studies that focused on different products, for which consumers'

12 acceptance and preferences may be inherently different. Thus, the different attitudes

13 shown by consumers across product categories may have played the role of a

14 confounding factor, impairing the authors' possibility to isolate patterns characterizing

15 consumption. Such heterogeneity in results conflicts also with other literature reviews

16 (such as Sirò et al., 2008; Lähteenmäki, 2013) which have instead found specific

17 patterns in the role of consumer-related characteristics, such as gender, age, and some

18 psychological variables, as well as a clear role of product-related characteristics in

19 shaping consumers acceptance for nutrition-modified and functional products. The

20 primary goal of this paper is to investigate if, by focusing in one specific product category,

21 dairy products, it is possible to isolate common patterns in consumers' acceptance and

22 preferences for nutrition-modified and functional foods by means of a systematic review

23 process. Our secondary goal is also to provide an integrated picture of the multiple elements

24 affecting the acceptance and preferences for dairy products. We chose dairy products as the

25 category of interest for two reasons. First, dairy products are one of the biggest market segment

26 among nutrition-modified and functional products, accounting for nearly $43 \%$ of the total 
1 worldwide sales (Ozer \& Kirmaci, 2010). Second, dairy products are considered by consumers

2 as one of the most credible product carriers to host functional ingredients, and consumers' acceptance and preferences towards nutrition-modified and functional dairy have been largely

4 investigated in literature (inter alia, Van Kleff et al., 2005; Ares \& Gambaro, 2007; Krutulyte

5 et al., 2008; Siegrist et al., 2008; Sirò, 2008; Ares et al., 2010).

6 Gaining more insight on consumers' preferences for a wide range of heath7 enhancing dairy products may benefit both dairy manufacturers and consumers, as it 8 will be illustrated throughout the manuscript. Furthermore, the results of this review, 9 along with its limitations, will help identifying avenues for future research, as it will be 10 illustrated in the final section of this article.

\section{Methods}

13 We used a systematic literature review methodology for the social sciences to 14 select articles from online academic search engines. Compared to narrative reviews, the 15 systematic literature review technique has the advantage of being based on an explicit and accurate study selection process which involves a multi-step procedure similar to 17 that used in research surveys (Cooper, 1998; Littell \& College, 2006). Additionally, the 18 systematic review process required findings to be weighted according to the quality of 19 the study they originate from; therefore an ad hoc quality assessment protocol was 20 built, based upon recommendations on how to assess social science papers (Littell et 21 al., 2008).

\section{Studies selection}

An initial inventory of relevant online databases was created. Scopus,

25 ScienceDirect, and Google Scholar were identified as search engines from which to retrieve the studies to be included in the review. Google Scholar, ScienceDirect and 
1 Scopus were selected as they use different approaches to index documents available on

2 the internet. Since ScienceDirect and Scopus only index title, abstract and keywords

3 documents containing search terms and keywords in the main text cannot be retrieved

4 during the search process from those web engines. Instead, Google Scholar can select

5 larger amount of documents compared to the other two search engines, as it indexes the

6 documents' main text. Thus, by using them jointly the likelihood of retrieving articles

7 related to the subject being investigated can be maximized (Ford, 2011).

8 The search process was restricted to research papers published in English in peer 9 reviewed journals from 1999 to 2013 . The choice of this time span was motivated by 10 the fact that nutrition-modified and functional products started to be introduced in the 11 market approximately at the end of the last century (Sirò et al., 2008) and by the time 12 when the articles were collected (November 2013).

13 As illustrated in figure 1, the selection process continued with three steps in which 14 inclusion/exclusion criteria reduced the number of studies gradually, by means of 15 structured queries developed using Boolean operators and two sets of keywords. The 16 first set of keywords included terms referring to the most frequently consumed 17 nutrition-modified and functional dairy products according to Sirò (2008): “cheese”, 18 "yogurt", "butter", "milk" and "spread". The second set of keywords included the 19 terms: "functional food", "vitamin", "omega-3", "fatty acid", "CLA" (Conjugated 20 Linoleic Acid), “calcium”, “antioxidant”, "probiotic", “prebiotic”, “fiber”, "low fat", 21 "light" and "low salt", which refer to the health-related attributes most frequently 22 attached to dairy products (Playne et al., 2003; Sirò, 2008). Finally, the term 23 "consumer" was added to the queries to identify only studies focusing on heath24 enhancing dairy products and consumers. 

via Google Scholar, and 1,722 via ScienceDirect. In the first step, the language of the

3 study and the type of publications (e.g. research papers, reviews, and books) were used

4 as selection criteria. In the second step, titles and abstracts of the remaining 2065

5 papers were inspected, retaining only those focusing on issues related to consumer

6 behavior and nutrition-modified/functional foods. In the third step, the remaining 109

7 studies were further reduced by excluding 31 studies that were duplicates, and 36

8 which focused on the sensory profiles of these products without assessing aspects

9 related to consumer behavior. It is worth pointing out that more than half of the 42

10 articles identified to be reviewed appeared multiple times among the final set of 109

11 papers: as the same paper was retrieved by two or all of the three search engines at the

12 beginning of search process. The final list of the 42 articles identified to be included in 13 this review is reported in table 1.

\section{Quality Assessment}

The quality assessment procedure is one of the steps in the systematic literature

17 review process differentiating it from other types of reviews (Littell \& College 2006;

18 Littell et al., 2008). This step requires the use of specific criteria to create a quality 19 score for each of the studies identified, and to produce a ranking of their quality. The 20 quality assessment was not easy to perform given the high heterogeneity of the 21 methodological approaches employed in this research domain, and because of the lack

22 of standardized quality assessment tools for studies belonging to the social science 23 field. 
Therefore, similarly to Cox et al. (2015), an ad hoc quality assessment tool was

2 developed using the Instrument Critical Appraisal Checklist (2009) provided by the

3 Joanna Briggs Institute as a reference document.

4 This quality assessment protocol consists of six criteria, identified according to the 5 authors' expertise (Appendix table A.1.).

6 The first criterion considered whether the analysis performed was qualitative or

7 quantitative in nature. The adequacy of the sample size used and whether the sample

8 was representative of a specific population group were the second and third criteria

9 considered. The remaining three criteria were whether the study included a theoretical

10 framework, whether confounding factors and biases were accounted for in the

11 empirical analysis performed, and if the outcome variable of the study was measured

12 using a validated measure and/or one objectively quantifiable (e.g. probability to

13 observe an outcome, willingness to pay, Likert scale). For more details see table A.1 in

14 the Appendix.

15 The studies identified were rated as low, medium, or high quality, based upon a 16 combination of the scores assigned to each of the six assessment criteria; equal

17 weighting was given to each criterion. A study was considered as "high quality" if it 18 rated "high" on three or more criteria; "medium quality," if it received two "high" or 19 one "high" and two "medium"; the remaining studies were classified as "low quality."

20 For a complete list of the papers' scores in all the criteria and their overall quality 21 rating, see table A.2 in the Appendix.

\section{Results}

Table 1 presents a summary of the identified studies' features. The majority of the 25 studies identified (23 out of 42) were ranked as "high" quality, whereas, about three 
1 quarters (32 out of 42), were ranked as either "high" or "medium" quality. The majority

2 of the studies, circa 80\%, were published between 2004 and 2013. Northern Europe,

3 North America and Uruguay were the geographical areas most investigated. In terms of

4 research design, 26 are single cross-sectional studies and show an average sample size

5 of 504 observations, with a minimum number of observations of 50 and a maximum of

$6 \quad 2,269 ; 8$ studies are multiple cross-sectional studies, with sample sizes ranging from 96

7 to 5,967 observations, for an average of 1,602; two are longitudinal studies, one is a

8 cohort study, and the remaining studies are based on exploratory research design (focus

9 group interviews). The age of the consumers interviewed ranges from 14 to 90 years of

10 age, with one study only focusing on consumers below the age of 30 , and another on

11 consumers above 65 years of age.

12 Generally speaking, the studies identified investigate aspects of consumer behavior

13 by comparing two or more food carriers delivering different health-related properties.

14 The most frequently investigated dairy food carrier, that is, the vehicle where bioactive

15 ingredients can be incorporated or modified (e.g. beverages, bread, cereal, margarine,

16 eggs), was yogurt (30 articles), followed by milk (11), cheese (10) and milk desserts

17 (4). With regard to the health-related attributes, probiotic, 'low fat content', and

18 omega-3 were the most studied (11 articles), followed by antioxidants (5), fiber (4),

19 calcium (4), vitamins (2) and iron (1).

20 In terms of the data analysis techniques used, most of the studies adopted

21 multivariate analysis techniques, such as analysis of variance or regression analysis.

22 Data reduction techniques, like cluster analysis and principal component analysis, were

23 employed in 9 out of 42 studies as intermediate techniques to identify consumers'

24 market segments on which to perform further analysis. For more details on the features

25 of the studies included in this review, see table A.2 in the Appendix. 


\subsection{Consumer related characteristics}

3

4

5

6 highlighting that women have higher levels of acceptance than men. Most of the

7 findings related to gender come from medium and high quality studies. For example,

8 Johansen et al. (2011) found more positive attitudes for low fat dairy products such as

9 yogurt and cheese among Norwegian, Danish and Californian female consumers,

\section{Gender}

The studies reviewed show the existence of a gender dimension in the acceptance and preference for nutrition-modified and functional dairy products, with most studies compared to men. High female acceptance was mainly due to the fact that low-fat products supported weight-control needs of many women which are, on average, also more health consciousness than men (Wardle et al., 2014). Ares \& Gambaro (2007) and Ares et al. (2009) pointed out that female consumers attached the highest values of willingness to try yogurts with added fiber or calcium. These dairy products were highly accepted compared to other functional concepts. Furthermore, female consumers showed positive attitudes for a functional dessert using milk as a base product (Ares et al., 2009), and a higher acceptance was especially recorded among individuals with a high level of personal involvement with the product (Ares et al., 2010a). A similar result was obtained by Hailu et al. (2009), who investigated a sample of Canadian consumers: these authors found that female consumers strongly prefer yogurt as a carrier to deliver probiotics rather than using pills or ice cream as a vehicle. Females' preferences for functional dairy products, especially for probiotic yogurt, also emerge from one high quality study performed by Annunziata and Vecchio (2013) on a representative sample of Italian consumers. 
Other findings from high quality studies using self-reported and actual

2 consumption data confirmed the presence of a gender dimension. Landström et al.

3 (2007) pointed out that female Swedish consumers part of a focus group study,

4 declared that they consume/purchase more functional products than males, with a

5 significantly larger share of probiotic milk products. De Jong (2003) instead, using a

6 multivariate type of analysis and a large dataset of actual consumption data from the

7 Dutch population, found weak evidence that being female is positively associated with

8 the consumption of yogurt with added lactic acid bacteria, while the same was not

9 found for males.

10 However, few medium (Peng et al., 2006; Ares et al., 2010b) and high quality

11 (Siegrist et al., 2008; Cox et al., 2011) studies, found no gender difference in the 12 acceptance of yogurts added with Conjugated Linoleic Acid (CLA) or omega-3 (Peng 13 et al., 2006; Cox et al., 2011), antioxidants (Ares et al., 2010b) and other unknown 14 ingredients conferring risk reduction or general function features to yogurt (Siegrist et 15 al., 2008). These results may be due to, respectively, a general lack of consumers' 16 interest (regardless of gender), for yogurts added with CLA or omega-3 (as discussed in 17 the next section); the lack of consumers' familiarity with the term "antioxidants"; and 18 the suspicion for health claims not related to specific functional compounds. Generally 19 speaking, product familiarity, trust, and suspiciousness, are elements strongly linked to 20 the novelty aspect of health-enhancing food products and may affect their acceptance 21 (Bower et al., 2003; Urala \& Lähteenmäki, 2007, Barrena \& Sanchez, 2010). Also, 22 Urala \& Lähteenmäki (2007) found no gender difference in the acceptance of 23 probiotic/stomach friendly yogurt and blood pressure lowering milk drinks, among 24 Finnish consumers, a result which may not be valid outside the Finnish sample/population surveyed. 
Thus, in the light of what is discussed above, the majority of the studies reviewed

2 converge in indicating females as the most likely consumers of nutrition-modified and

3 functional dairy products and particularly for products providing benefits linked to

4 intestinal well-being, weight loss and bone health. Functional dairy products promoting

5 bone health appear to be strongly preferred among females because of their higher risk

6 (compared to males) of developing osteoporosis (Ares \& Gambaro, 2007; Hailu et al., 7 2009).

10 There is a general consensus among scholars that being older is positively 11 associated with a higher interest in dairy products with health-enhancing features, 12 especially for functional products with disease risk reduction properties. High quality 13 studies conducted by Urala \& Lähteenmäki $(2004 ; 2007)$ on a sample of Finnish 14 consumers found that older respondents were more willing to use functional foods with 15 claims to reduce the risk of a disease, such as blood pressure lowering milk drinks 16 (Urala \& Lähteenmäki, 2004;2007). Older respondents seem to perceive these products 17 as more rewarding than younger consumers, since they can help counteract health 18 issues related to aging (Urala \& Lähteenmäki, 2007). The perceived reward from 19 consuming functional foods, including functional dairy products, was indicated as 20 highly predictive of the willingness to use them (Urala \& Lähteenmäki, 2004; 2007).

21 This result was also confirmed by another high quality study by Messina et al. (2008) 22 investigating a large cross-country sample of older consumers. These authors suggested 23 that their results may be due to older consumers having been exposed longer to 24 functional products compared to younger ones (Messina et al., 2008; Urala \& 25 Lähteenmäki, 2004; 2007). Thus, older consumers have more knowledge and 
1 familiarity with functional dairy products and their effects on health, and are more

2 likely to accept them.

3 Additional evidence, from high (Siegrist et al., 2008; Øvrum et al., 2012) and

4 medium quality studies (Peng et al, 2006; Ares \& Gambaro, 2007; Ares et al., 2009),

5 corroborates the existence of a relationship between aging consumers and higher

6 acceptance of nutrition-modified and functional dairy products, confirmed by medium

7 and high quality studies using both self-declared and actual purchase data. Mullie et al.

8 (2012) recorded higher self-declared consumption of low fat dairy among older Belgian

9 consumers. Also, de Jong et al. (2003) found that being 65 or older is associated with

10 higher consumption of many functional products, including functional yogurt with

11 lactic acid bacteria (de Jong et al., 2003). Both Bonanno's (2012) study using Italian

12 actual purchase data, and Chase et al.'s (2009) study of Canadian consumers, found

13 that consumers increase their demand for functional yogurts and omega-3 added dairy

14 products as they grow older.

15 Younger consumers instead show overall higher acceptance for products enhancing

16 some physiological functions, such as those improving general well-being or those that

17 help prevent fatigue, compared to older respondents, as supported by a high (Urala \&

18 Lähteenmäki, 2004) and a medium quality (Hailu et al., 2009) study. Only one study

19 found no difference in the acceptance for functional dairy products among individuals

20 belonging to different age groups (Landström et al., 2007).

21 In summary, the majority of studies identified in this systematic literature review

22 suggests that older consumers are more likely to accept willing to try, and to include

23 both nutrition-modified and functional dairy products in their diet. Older individuals

24 may constitute, along with women, the group of consumers most receptive to such

25 products, especially for functional products claiming to reduce the risk of diseases. 
The studies reviewed found that variables related to consumer's level of knowledge

4 about the relationships between health and nutrition (Ares et al., 2008, Øvrum et al.,

5 2012) and in general to the consumer's nutritional knowledge, (Labrecque et al., 2006;

6 Whaba et al., 2006; Viana et al., 2008; Barenna \& Sanchez, 2010) are good predictors

7 of consumer acceptance of some dairy products, such as probiotic yogurts, low-fat

8 products as well as products with added calcium, antioxidant and fiber. However, some

9 of the studies reviewed did not use validated measures to assess consumers'

10 knowledge, thus their results may need further validation by means of validated scales.

11 For example, Ares et al. (2008) exploring the role of nutritional knowledge on the

12 functional dairy acceptance, used an ad hoc modification of the Nutrition Knowledge

13 Questionnaire, developed by Parmenter and Wardle (1999) without assessing its 14 validity.

15 An additional hurdle in assessing the effect of consumers' diet-health related 16 knowledge on the acceptance of (and preference for) functional dairy products is that 17 many other factors can affect this relationship, for example family size. In families with 18 young children (below 12 years of age) parents feel more responsible for their health 19 (Barrios et al., 2008; Annunziata \& Vecchio, 2013) and that may push them to acquire 20 more nutritional-, diet- and health-related knowledge. A similar increase can arise in 21 individuals who have had direct or indirect experience with illnesses, due to the 22 enhanced receptiveness to information regarding diet and health related issues (Van 23 Kleef, 2005a; Annunziata \& Vecchio, 2013). Given the many factors affecting diet and 24 health-related knowledge, more analyses using multivariate analysis methods, 25 including mediation analysis, may be needed to isolate the role of nutritional/diet- 
1 health knowledge on consumer acceptance of nutrition-modified and functional dairy

2 products.

3 Lastly, evidence from high quality studies points to a general consensus for

4 lifestyle variables (such as practicing sport and taking supplements) influencing the

5 acceptance of nutrition-modified and functional dairy products, as "wellness oriented"

6 consumers appear more willing to trade the taste of food for health benefits (Zandstra et

7 al., 2001; Landström et al., 2007). Although, at first glance, the group of health oriented

8 consumers may be seen as the ideal target for health-enhancing products, they represent

9 only a niche market. Food manufacturers' efforts could otherwise be directed to

10 improve the taste of functional and nutrition-modified dairy products as a means to

11 enlarge their potential market and to reduce their price, which are often indicated as

12 barriers to health-enhancing products' consumption (Frewer et al., 2003; Landstrom et

13 al., 2009).

Many of the studies reviewed explored how psychological factors, recorded 17 through specific scales, can influence consumers' preferences for health-enhancing 18 products. Among the studies surveyed, some investigated the role of consumers' 19 attitudes towards health and taste, on the acceptance of nutrition-modified and 20 functional dairy products, employing the health and taste scale originally developed by 21 Roinenen et al. (1999).

22 Two high quality studies, conducted by Landström et al. (2007) and Zandstra, de 23 Graaf, \& Van Staveren (2001) on samples of Swedish and Dutch consumers, 24 respectively, found that consumers who scored higher values of the 'general health interest' and 'light product interest' scales, recorded higher consumption of low-fat

26 dairy products, conversely to those scoring higher for 'craving for sweet'. Also, 
1 according to another high quality study conducted by Labrecque et al. (2006), the

2 attitudes towards health and taste may also contribute to explain cross-cultural

3 preferences toward milk with omega-3 between Canadian, French and American

4 students, despite their low frequency of consumption.

5 Two successive high quality studies by Urala and Lähteenmäki $(2004 ; 2007)$

6 argued that functional foods differ from "conventional" healthy foods and thus the

7 general health scale was expected to be a weak predictor of consumers' functional food

8 choices. Therefore, they developed and used seven scales to predict the willingness to

9 consume selected functional foods. These authors found that the "perceived reward of

10 improving your own health and performance" best predicted consumers' willingness to

11 use milk added with calcium, blood pressure lowering milk drinks, and low-fat cheese.

12 However, although the perceived reward from consuming functional foods may predict

13 Finnish consumers' willingness to use functional dairy products, this result may not

14 apply to other cultures, as culture and food habits vary across countries. Therefore,

15 more cross-cultural studies are needed to confirm that perceived reward plays a role in

16 predicting consumers' use of functional dairy products.

17 Furthermore, as some functional foods are created by adding a bioactive ingredient

18 to a food carrier, adding an external ingredient can influence acceptance of the overall

19 product. Scholars have investigated consumers' acceptance of new functional

20 ingredients-dairy products combinations by using the food-neophobia scale, originally

21 proposed by Pliner \& Hobden (1992). Empirical evidence from high quality studies

22 shows that food-neophobia is negatively correlated with the consumers' willingness to

23 buy probiotic yogurt, whereas it does not affect consumers' willingness to buy other

24 non-dairy functional products (Siegrist et al., 2008). Also, Urala \& Lähteenmäki (2007)

25 report that consumers' neophobia was negatively correlated with the willingness to use 
1 probiotic yogurts, but that it does not affect the use of other functional products, like

2 cholesterol-lowering spreads or milk with claims to lower blood pressure. On the one

3 hand, it is likely that food-neophobia may play a different role in relation to different

4 combinations of functional ingredients and carriers. On the other hand, results may be

5 confounded by the fact that, for consumers with high cholesterol blood level, there is a

6 "virtual prescription" for cholesterol lowering products, and that medical applications

7 have been found to suppress neophobia, or risk perception (Alevizos, Mihas \& Mariolis

8 2007). Therefore, Urala \& Lähteenmäki (2007) findings may be biased as they did not

9 account for the existence of cholesterol related problems in any of their respondents.

10 Since products with health-enhancing features are of recent market introduction,

11 the relationship between consumers' attitudes towards food innovation and the

12 acceptance of such new products has been the object of investigation in some of the

13 studies included in this review. Almli et al. (2011) conducted a cross-cultural study

14 where French and Norwegian consumers were asked to state their preferences toward

15 traditional cheese added with omega-3. In neither country the addition of omega-3 in

16 traditional cheeses showed a positive effect on the willingness to buy such product.

17 Even though the results from Almli et al. (2011) suggest the existence of consumers'

18 aversion towards innovative health-food solutions, their results may be in part due to

19 consumers' aversion to the match of omega-3 with dairy products, amply documented

20 in the next section.

21 A different approach was employed by Cox, Evans \& Lease (2007), in their high

22 quality study. Using a Protection Motivation Theory framework (Rogers et al., 1975),

23 these authors found that perceived self-efficacy was the best predictor of the likelihood

24 of purchasing milk with omega-3 among a sample of Australian consumers. Compared

25 to other carriers containing omega-3, the authors found that omega-3-enriched milks 
1 were the least likely to be purchased (Cox, Evans \& Lease 2007). Also, a low quality

2 study by Barrena and Sanchez (2010) used a means-end chain approach on a sample of

3 sixty Spanish households to link their knowledge of bifidus added to yogurt and milk,

4 to consequences and personal values related to this product, finding a major personal

5 dimension in the purchase and consumption of bifidus-added dairy among households

6 with children.

7 In summary, these studies find that psychological factors contribute to shape 8 consumers' acceptance for nutrition-modified and functional dairy products.

9 Consumers can become more interested in these products once they can

10 perceive/believe in their health enhancing properties (for themselves and/or for people

11 close to them). However, all the studies reviewed focus on North European consumers;

12 therefore, research conducted in other Southern countries may be useful for food 13 manufacturers as functional food markets are fast growing. For example, Italy saw the 14 highest number of new healthy products launch among European Countries between 152005 and 2009 (Nutraingredients, 2009).

\section{2 . Product related characteristics}

Models assessing consumer acceptance and preferences by accounting for product

19 characteristics populate the literature, along with those that explored consumers'

20 perceived healthiness of many combinations of carriers and ingredients.

Intrinsic product characteristics

Intrinsic product characteristics can be defined as any informational stimuli of the

24 physical product which cannot be changed without altering the essence of the product

25 itself (Poulson et al., 1996). In the case of nutrition-modified and functional foods, 
1 intrinsic product characteristics are given by the combination of the health-enhancing

2 ingredient with the type of carrier used.

3 Scholars' interest in consumers' perceived healthiness toward nutrition-modified

4 and functional foods was due to the fact that the latter is highly correlated with the

5 market success of the product and it was found being influenced by both intrinsic and

6 extrinsic product characteristics (discussed in the next session). Consumers' perceived

7 healthiness is usually measured on a sevem-point Likert scale ranging from 1, 'not

8 healthy', to 7, 'extremely healthy' (Bech-Larsen \& Grunert, 2003). The combinations

9 of carriers and ingredients receiving the highest perceived healthiness scores are more

10 likely to be accepted by consumers, and to succeed in the marketplace (Grunert, 2000;

11 Bech-Larsen \& Grunert, 2003; Krutulyte et al., 2008, 2011; Johansen et al. 2011; Cox

12 et al., 2011).

13 Several of the studies identified in this review have investigated the perceived 14 healthiness of carriers, ingredients and their combinations. Studies with different 15 quality levels show that the perceived healthiness of a dairy product largely depends 16 upon the consumer's perceived healthiness of the carrier (Ares et al., 2008; Hailu et al., 17 2009); others (van Kleef et al., 2005a; Hailu et al., 2009; Johansen et al., 2011) pointed 18 to yogurt being perceived as the healthiest carrier among those tested, perhaps because 19 yogurt is perceived as intrinsically healthy.

20 Furthermore, a number of mostly high quality studies among those reviewed, also

21 indicate that consumers show strong acceptance for selected ingredients such as 22 calcium and fiber, and a more positive perceived healthiness of health-enhancing foods 23 where the bioactive ingredient is "naturally added" or it is inherent to the carrier (Cox 24 et al., 2011; Krutulyte et al., 2008, 2011). For example, yogurt with added calcium is 25 perceived as healthier than yogurt with added fibers, antioxidants and iron (Ares \& 
1 Gambaro, 2007). Instead, yogurts added with omega-3 are perceived negatively, since

2 they are characterized by a combination perceived as less natural than, for example,

3 omega-3 and fish products (Krutulyte et al., 2011). Additionally, consumers struggle to

4 associate the fish taste of omega-3 with the sweetness of yogurt, and are skeptical of

5 the potential off-flavors produced by the addition of such ingredient to yogurt

6 (Krutulyte et al., 2011). Low consumer acceptance for dairy products added with

7 omega-3 was also confirmed by Chase et al. (2009) using Canadian purchase data

8 matched with household related information. They found that more than $90 \%$ of the

97,947 households surveyed never purchased omega-3 added products. However,

10 moderate acceptance of omega-3 modified dairy products was recorded among

11 individuals who perceived the risk of conditions associated with a metabolic syndrome

12 (O'Brien et al., 2012).

13 Limited evidence exists, from medium and high quality studies, in support of the

14 effectiveness of adding "external" ingredients to products considered unhealthy in

15 order to improve their acceptance. In some cases, carriers with an unhealthy image,

16 such as cheeses or spreads, known for their high cholesterol content, were perceived as

17 good carriers for bioactive ingredients such as polyunsaturated fat or omega-3,

18 mitigating the negative effect of cholesterol on health (Bech-Larsen \& Grunert, 2003;

19 Peng et al., 2006). In these cases consumers may simply prefer health-enhancing dairy

20 products whose bioactive ingredients "enhance" the innate or intrinsic properties of the

21 product without altering its sensory characteristics, regardless on whether the ingredient

22 is a "natural" addition to the carrier or it is exogenous to it.

23 Given the findings presented above, there appears to be a widespread consensus

24 in the literature that a "natural" match between added ingredient and carrier increases

25 the overall acceptance of functional dairy products with health-enhancing features. 
Extrinsic product characteristics are informational stimuli which are not

4 physically part of the product, e.g. a product's label and its elements (Grunert et al.,

5 1996). In the case of food products with health-enhancing features, extrinsic attributes

6 are nutrition and health claims available on the labels, a product's brand, and its

7 package. These characteristics work usually as tools to inform consumers about the

8 product's properties, and to attract and influence shoppers' purchasing decisions. The

9 existing literature provides conflicting results on how nutrition and health claims affect

10 consumers' acceptance of nutrition-modified and functional dairy products (Bech-

11 Larsen \& Grunert, 2003; Ares et al., 2009; Ares et al., 2010b). A medium and a high

12 quality study identified in this systematic review suggest that individuals prefer dairy

13 food products with health and nutrition claims rather than identical ones without a

14 claim, suggesting that the presence of a claim increases the healthiness perception of

15 products and therefore their acceptance (Bech-Larsen \& Grunert, 2003; Ares et al.,

16 2009). A high quality study by Lähteenmäki et al. (2010) found no effect, or a slightly

17 negative one, of the presence of health claims on consumer perceived healthiness by

18 investigating a large sample of north European consumers.

19 Results of high quality studies indicate that the presence of nutrition and health

20 claims may guide some groups of consumers in making healthier food choices (Marette

21 et al., 2010; Øvrum et al., 2012), and that these consumers are also willing to pay a

22 premium price for those food products. In particular, female consumers with diet-health

23 knowledge (Øvrum et al., 2012) and consumers with chronic diseases (Marette et al.,

24 2010) seem to be the groups who are both willing to pay higher prices for dairy

25 products with health-enhancing features, and to take nutrition and health claims into 
1 account in their food decisions process (Marette et al., 2010; Øvrum et al., 2012).

2 However, some evidence from low/medium quality studies indicates that the presence

3 of nutrition claim generates negative effects on consumers' perceived pleasantness

4 from the consumption of reduced fat dairy products (Kähkönen \& Tuorila, 1999,

5 Johansen et al., 2011), effectiveness which is mitigated in health-conscious consumers

6 committed to healthy eating habits, and less demanding about food taste (Johansen et

7 al., 2011).

8 Health claims guarantee different levels of health efficacy and convey different

9 health benefits (e.g. cholesterol reducing effects, support of the immune system, and 10 support of bone health) (Bimbo et al., 2016). A high (van Kleef et al., 2005a) and a

11 medium quality (Williams et al., 2008) study suggest that, among the many claims

12 available in the marketplace, consumers prefer overall health claims to nutrition claims,

13 and risk disease reduction claims to general function ones. Interest in risk reduction

14 claims is found in highly educated consumers, often females, who have been directly or

15 indirectly exposed to diseases, in consumers with a high level of diet-health related

16 knowledge (Williams et al., 2008; Ares et al., 2010b), and in those using nutritional

17 supplements (Hailu et al., 2009). Similar findings were reported by Annunziata \&

18 Vecchio (2013) in their high quality study. These authors identified a consumer cluster

19 composed mainly of highly educated females with children under 12 years of age, and

20 of consumers adopting healthy diets, who preferred dairy products with risk reduction

21 claims rather than other claims; the other cluster of respondents in their sample

22 preferred generic claims related to the enhancement of general well-being (Annunziata

$23 \&$ Vecchio, 2013).

24 The results presented above do not depict clear patterns in consumers' acceptance

25 for nutrition and health claims available in the market place. Results seem to vary 
1 according to how relevant a specific nutritional/health claim is, for the group of

2 consumers examined. However, many high quality studies point to woman with diet-

3 health knowledge, individuals with chronic diseases, and highly educated consumers,

4 as those consumers groups which are more likely to take into account nutrition and

5 health claims in their food choices, as well as to pay higher price for health-enhanced

6 dairy versions. Additionally, consumers interested in dairy products with health claims

7 may have a higher ability to understand them and to process the information conveyed

8 by the health claims (Nocella \& Kennedy, 2012). Furthermore, claims are often

9 formulated in complicated terms: shorter, easier to understand claims, may increase the

10 acceptance of functional dairy products and facilitate the recovery of the high

11 investment costs undertaken to develop and to market them (Siegrist et al., 2008).

12 With regard to brand, Deliza \& MacFie (1996) identify it as one of the most

13 important extrinsic attributes influencing consumers' purchasing decisions for food

14 products. Brands can signal quality and the manufacturer's guarantee of the truthfulness

15 of what is declared on the package (Deliza \& MacFie, 1996). Similar findings emerge

16 from studies investigating consumer acceptance and preference for nutrition-modified

17 and functional dairy products (Ares et al., 2010a; Ares \& Deliza, 2010; Barrena \&

18 Sanchez, 2010; Annunziata \& Vecchio, 2013).

19 The high quality study by Messina et al. (2008) showed that the influence of brand

20 on older consumers' choices differs across countries, as older consumers from South

21 America and Southern Europe are influenced more than those from other countries.

22 Among medium quality studies, Ares et al. (2010a) found that brand affects willingness

23 to purchase functional milk dessert, while Ares et al. (2010b) found that brand was the

24 second attribute for magnitude, after carrier, to affect consumer choice of functional 
1 yogurts, and that the impact is as high as carrier, in affecting consumer's preferences

2 among middle aged females.

3 Similar results emerge from the high quality study performed by Annunziata \&

4 Vecchio (2013), where brand affects the choice of probiotic yogurts among a segment

5 of young Italians with an average level of education, lower probability to engage in

6 healthy eating habits, and low consumption frequency of probiotic dairy yogurt

7 (Annunziata \& Vecchio, 2013); the same study also finds that brand's effect in shaping

8 consumers' choices increases with consumers' familiarity with the brand, while brands

9 do not affect food decisions in consumers with interest in health (Annunziata \&

10 Vecchio, 2013), confirming findings of other studies (Barrios et al., 2007; Ares et al., 11 2010b).

12 Results of medium and high-quality studies supporting the notion that the brand 13 positively affects consumers' attitudes and preference toward health-enhancing dairy 14 products, were also found in two of the low-quality studies reviewed (Barrena \& 15 Sanchez, 2010; Ares \& Deliza, 2010). Barrena \& Sanchez (2010) found that brand 16 familiarity is one of the product's characteristics evaluated by households during their 17 decision process to purchase probiotic milk (Barrena \& Sanchez, 2010), while Ares \& 18 Deliza (2010) pointed out that brand was one of the most frequently mentioned item, 19 after flavor, color and shape of the package among nutrition-modified milk desserts' 20 packages features influencing purchases (Ares \& Deliza, 2010).

21 The findings presented above show a general consensus among the literature 22 reviewed that brand increases the acceptance and motivates consumers' choice of 23 nutrition-modified and functional dairy products over conventional ones. Such 24 influence is particularly strong among consumers who are less likely to engage in a 25 healthy lifestyle, while they have little to no effect on the choices of consumers with 
1 high interest in health. However, these results may be confounded by country-specific

2 differences in education, in the proportion of individuals engaging in healthy lifestyles,

3 and in the development stage of the health-enhancing foods' market. Last, packaging is

4 another extrinsic product characteristic that attracts consumers' attention and can

5 influence their purchasing decisions of health-enhancing dairy products. Among the

6 studies identified, we found little emphasis on this factor. Ares \& Deliza (2010)

7 explored the effect of packaging's attributes on consumer willingness to purchase

8 nutrition-modified chocolate milk desserts. They found that the color and shape of

9 packaging influence consumers' purchasing decisions and that brown packaging

10 increases consumers' purchasing intentions for such dessert. Packaging shape, instead,

11 shows mixed effects on consumers' intention to purchase a low-fat dessert, depending

12 upon the expectations regarding the product's texture that the package shape generates

13 in the consumers' minds (Ares \& Deliza, 2010). In summary, Ares \& Deliza's (2010)

14 study proves that package's features affect consumers' acceptance and purchasing

15 decisions, however more research is needed on this topic to corroborate the results of 16 this study.

existing knowledge on consumers' acceptance and preferences toward nutritionmodified and functional dairy products. The quality of the studies identified was assessed by means of an ad hoc tool, and the studies' findings organized to give an overview of major factors influencing consumer behavior toward these products.

Overall, the findings of our systematic review support the existence of clear patterns characterizing consumers' acceptance and preferences for nutrition-modified 
1 and functional dairy products, differently than previous systematic reviews including

2 studies covering different product categories (Ozen et al., 2012; Ozen et al., 2014) and

3 in line with other reviews on consumer acceptance and preferences for health-

4 enhancing food products (e.g. Frewer's et al. 2003; Siro's et al. 2008; and

5 Lähteenmäki, 2013).

6 Our results confirm that gender and age play an important role in explaining

7 different patterns of acceptance in relation to identified combinations of carriers and

8 ingredients. Female consumers are more willing to use, and to include in their diet

9 yogurt enriched with calcium, fiber and probiotics as well as consuming low-fat dairy

10 products. Willingness to use/purchase functional and nutrition-modified dairy products

11 increases with age, as older consumers perceive higher rewards from consuming such

12 food versions, and show more interest in health. Therefore, female and older consumers

13 characterize the groups of consumers likely to be most receptive to nutrition-modified

14 and functional dairy products; as elderly people are the main users of resources within

15 healthcare systems, and through promoting the consumption of dairy products with

16 health enhanced features may improve their health and may have a beneficial impact on

17 reducing national health care expenditure.

18 Our findings also support that diet-health and nutritional knowledge contribute to

19 explain consumers' acceptance of nutrition-modified and functional dairy products;

20 however, more research is needed in this area as most of the studies identified have

21 used non-validated scales to assess this relationship. Consumer psychological traits also

22 contribute to shape consumers' acceptance and preferences for nutrition-modified and

23 functional dairy products. Among intrinsic product attributes, carriers appear as the

24 most effective in influencing consumers' perceived healthiness; their effect is positive

25 when a "natural" match between the carrier and the bioactive ingredient exists, and 
1 negative for "unnatural" matches, such as omega-3 added to yogurt. More research is

2 needed on the role of different nutrition and health claims, as the existing literature

3 provides conflicting results which may largely depend on the relevance of the nutrition

4 or the health claim surveyed for the sample selected.

A novel result of this systematic review is that extrinsic product's characteristics

6 such as a product's brand, and its package's features affect strongly consumers' choices

7 for nutrition-modified and functional dairy products. Some of the studies included in

8 this review pointed at brand as being the second most important product attribute, after

9 the carrier, affecting consumers' evaluation of yogurt added with fiber and antioxidant.

10 Also, brand recognition drives consumers' choice of yogurt with general functional

11 claims among middle age Italian females with a sedentary lifestyle, and among Spanish

12 households with children. Instead, a product's brand does not play a role when

13 consumers chose dairy products with risk-reduction health claims. Further, we

14 identified one study exploring consumers' preferences for package's characteristics of

15 nutrition-modified food products, which found that the package's features, such as its

16 color, shape the consumer's preferences for low fat milk dessert shape consumers'

17 expectations about the food product.

18 These novel findings may provide beneficial for manufacturers of nutrition-

19 modified and functional dairy products, as they suggest the need to invest in building

20 brand reputation to ensure market success. However, as consumers' interest in disease

21 risk reduction claims does not seem affected by brand familiarity, firms investing in

22 risk reduction claims may find it more profitable to focus their efforts in claim-

23 developing activities, rather than in brand advertising. Furthermore, the success of

24 nutrition-modified and functional products may be facilitated by marketing activities 
1 focusing on creating food packages which attract the consumers' attention and interest

2 for such products.

3 Our study has three main limitations. First, our findings apply only to the

4 acceptance and preferences for dairy products, and, as such, our analysis is limited in

5 scope. Future research should focus on assessing consumer's behavior for others food

6 categories, as well as the interrelationships between cross categories choices, which

7 does not seem to have been explored so far.

8 Second, even though we are aware that taste stimuli play a pivotal role in food

9 choices, and that a functionality/nutrition-modified feature provides added value to

10 consumers as long as it doesn't modify the sensory properties of a food product original

11 food (Verbeke, 2005; Bech-Larsen and Scholderer, 2007), we excluded this bulk of

12 literature from this study as it is too vast and it deserves its own analysis. Thus, future

13 research should account for the role played by taste stimuli on consumer's choices of

14 functional/nutrition-modified food products.

15 Third, even though we aimed to provide a comprehensive picture of the many

16 drivers affecting consumer acceptance and preferences for nutrition-modified and

17 functional dairy products, the majority of the findings analyzed came from studies

18 performed in Northern European countries, with few from Southern European and

19 American countries. Therefore, in order to understand cultural, psychological and other

20 aspects of purchasing behavior in other national contexts, more research needs to be

21 conducted in Mediterranean, American and Asian countries. Expanding the pool of

22 countries subject of analysis can allow food companies to reach international audiences

23 more effectively.

24 The findings of this review also open to the possibility of new avenues of research.

25 In the first place, some of our findings indicate that brand affects consumer's food 
1 choices when it is associated with nutrition and health claim. Future research should

2 explore the possibility that consumers' acceptance and preferences for a product's

3 feature may vary conditionally on the support provided by different brands. As it is

4 well-known that a brand name may act as an additional guarantee of a label's

5 truthfulness, more research on the interaction of different types of brand names and

6 consumers' attitude towards specific features may provide beneficial for food

7 manufacturers.

8 Last, it should be mentioned that none of the studies reviewed was conducted using

9 methods aimed to improve the realism of choice experiments, such as virtual reality-

10 based methods. As those methods are meant to increase their external validity (Van

11 Herpen et al., 2016) they lend for their results to be more comparable across studies,

12 which was one of the hurdles we faced in this systematic review and which is, in

13 general, due to the fact that survey-based methods show high heterogeneity in study

14 design (Van Kleef et al., 2005b). Future research should consider exploiting these new

15 tools to corroborate the findings of survey-based research and, when a numerous

16 enough body of research is available, to validate the findings of this review.

\section{Acknowledgments}

19 Authors are grateful to founders of project PON 01_00851 "Bioinnovation for high

20 healthy value dairy production".

\section{References}

22 Almli, V.L., Næs, T., Enderli, G., Sulmont-Rossé, C., Issanchou, S. \& Hersleth, M. 23 (2011). Consumers' acceptance of innovations in traditional cheese. A 24 comparative study in France and Norway. Appetite, 57, 110-120.

25 Alevizos, A., Mihas, C., \& Mariolis, A. (2007). Advertising campaigns of sterol 
enriched food. An often neglected cause of reduced compliance to lipid lowering drug therapy. Cardiovascular Drugs and Therapy, 21(2), 133-134.

Annunziata, A., \& Vecchio, R. (2013). Consumer perception of functional foods: A conjoint analysis with probiotics. Food Quality and Preference, 28, 348-355.

Ares, G., \& Deliza, R. (2010). Identifying important package features of milk desserts using free listing and word association. Food Quality and Preference, 21, 621628.

Ares, G., \& Gámbaro, A. (2007). Influence of gender, age and motives underlying food choice on perceived healthiness and willingness to try functional foods. Appetite, $49,148-158$.

Ares, G., Besio, M., Giménez, A., \& Deliza, R. (2010a). Relationship between involvement and functional milk desserts intention to purchase. Influence on attitude towards packaging characteristics. Appetite, 55, 298-304.

Ares, G., Giménez, A., \& Deliza, R. (2010b). Influence of three non-sensory factors on consumer choice of functional yogurts over regular ones. Food Quality and Preference, 21, 361-367.

Ares, G., Giménez, A., \& Gámbaro, A. (2009). Consumer perceived healthiness and willingness to try functional milk desserts. Influence of ingredient, ingredient name and health claim. Food Quality and Preference, 20, 50-56.

Ares, G., Giménez, A., \& Gámbaro, A. (2008). Influence of nutritional knowledge on perceived healthiness and willingness to try functional foods. Appetite, 51, 663668.

Barrena, R., \& Sánchez, M. (2010). The link between household structure and the level of abstraction in the purchase decision process: an analysis using a functional food. Agribusiness, 26, 243-264.

Barrios, E.X., Bayarri, S., Carbonell, I., Izquierdo, L., \& Costell, E. (2008). Consumer Attitudes and Opinions Toward Functional Foods: A Focus Group Study. Journal of Sensory Studies, 23, 514-525.

Bech-Larsen, T., \& Grunert, K.G. (2003). The perceived healthiness of functional foods: A conjoint study of Danish, Finnish and American consumers' perception 
of functional foods. Appetite, 40, 9-14.

2 Bech-Larsen, T., \& Scholderer, J. (2007). Functional foods in Europe: consumer research, market experiences and regulatory aspects. Trends in Food Science \& Technology, 18(4), 231-234.

5 Bigliardi, B., \& Galati, F. (2013). Innovation trends in the food industry: The case of functional foods. Trends in Food Science \& Technology, 31, 118-129.

Bimbo, F., Bonanno, A., \& Viscecchia, R. (2016). Do health claims add value? The role of functionality, effectiveness and brand. European Review of Agricultural Economics, 43(5), 761-780.

Bleiel, J. (2010). Functional foods from the perspective of the consumer: How to make

Cox, D. N., Hendrie, G. A., \& Carty, D. (2015). Sensitivity, hedonics and preferences 
comprehensive review. Food Quality and Preference, 41, 112-120.

2 de Jong, N., Ocké, M.C., Branderhorst, H.A.C. \& Friele, R. (2003). Demographic and lifestyle characteristics of functional food consumers and dietary supplement users. British Journal of Nutrition, 89, 273-281.

5 Deliza, R., \& MacFie, H.J.H. (1996). The generation of sensory expectation by external cues and its effect on sensory perception and hedonic ratings: A review. Journal of Sensory Studies, 11, 103-128.

8 Food and Drug Administration (FDA) (2013). Guidance for Industry: A Food Labeling

Ford, N. (2011). The essential guide to using the web for research. Thousand Oaks,

Guide available at http://www.fda.gov/Food/GuidanceRegulation/GuidanceDocumentsRegulatoryIn formation/LabelingNutrition/ucm2006828.htm last access 26/10/2015.

$$
\text { CA: Sage. }
$$

Frewer, L., Scholderer, J., \& Lambert, N. (2003). Consumer acceptance of functional foods: issues for the future. British Food Journal, 105(10), 714-731.

Grunert, K. G., Hartvig Larsen, H., Madsen, T. K., \& Baadsgaard, A. (1996). Market Orientation in Food and Agriculture. Norwell, MA: Kluwer.

Grunert, K. G., Bech-Larsen, T., \& Bredahl, L. (2000). Three issues in consumer quality perception and acceptance of dairy products. International Dairy Journal, 10(8), 575-584.

Hailu, G., Boecker, A., Henson, S., \& Cranfield, J. (2009). Consumer valuation of functional foods and nutraceuticals in Canada. A conjoint study using probiotics. Appetite, 52, 257-265.

Hardy, N. (2010). Future Innovations in Food and Drinks to 2015, Report No. BI00014-024, Business Insights, London.

Heasman, M., \& Mellentin, J. (2001). The Functional Foods Revolution: Healthy People, Healthy Profits?, Earthscan Publications Ltd, London. 
1 Hendrie, G. A., Coveney, J., \& Cox, D. (2008). Exploring nutrition knowledge and the demographic variation in knowledge levels in an Australian community sample. Public Health Nutrition, 11(12), 1365-1371.

Joanna Briggs Institute. (2009). Comprehensive systematic review module 3: The systematic review of quantitative evidence.

Johansen, S.B., Næs, T., \& Hersleth, M. (2011). Motivation for choice and healthiness perception of calorie-reduced dairy products. A cross-cultural study. Appetite, 56, $15-24$.

Kähkönen, P., \& Tuorila, H. (1999). Consumer responses to reduced and regular fat content in different products: effects of gender, involvement and health concern. Food Quality and Preference, 10, 83-91.

Khan, R.S., Grigor, J.V., Win A.G., \& Boland, M. (2014). Differentiating aspects of product innovation processes in the food industry. British Food Journal, 116(8), 1346-1368.

Krutulyte, R., Grunert, K.G., Scholderer, J., Hagemanna, K.S., Elgaarda, P., Nielsena, B., \&Graverholt, J.P. (2008). Motivational factors for consuming omega-3 PUFAs: An exploratory study with Danish consumers. Appetite, 5(1), 137-147.

Krutulyte, R., Grunert, K. G., Scholderer, J., Lähteenmäki, L., Hagemann, K. S., Elgaard, P., Nielsen, B., \& Graverholt, J. P. (2011). Perceived fit of different combinations of carriers and functional ingredients and its effect on purchase intention. Food Quality and Preference, 22(1), 11-16.

Labrecque, J., Doyon, M., Bellavance, F., \& Kolodinsky, J. (2006). Acceptance of Functional Foods: A Comparison of French, American, and French Canadian Consumers. Canadian Journal of Agricultural Economics/Revue canadienned'agroeconomie, 54, 647-661.

Landström, E., Hursti, U.-K.K., Becker, W., \& Magnusson, M. (2007). Use of functional foods among Swedish consumers is related to health-consciousness and perceived effect. British Journal of Nutrition, 98, 1058-1069.

Landström, E., Hursti, U.-K.K., \& Magnusson, M. (2009). Functional foods compensate for an unhealthy lifestyle. Some Swedish consumers' impressions and perceived need of functional foods. Appetite, 53, 34-43. 
1 Lähteenmäki, L., Lampila, P., Grunert, K., Boztug, Y., Ueland, Ø., Åström, A., \&

2 Martinsdóttir, E. (2010). Impact of health-related claims on the perception of

3 other product attributes. Food Policy, 35(3), 230-239.

4 Lähteenmäki, L. (2013). Claiming health in food products. Food Quality and

$5 \quad$ Preference, 27(2), 196-201.

6 Littell, J.H., \& College, B.M. (2006). Systematic Reviews in the Social Sciences: A $7 \quad$ Review. Evidence \& Policy, 2(4), 535-537.

8 Littell, J.H., Corcoran, J., \& Pillai, V. (2008). Syematic Reviews and Meta-Analysis. $9 \quad$ Oxford University Press.

Maynard, L.J. (2005). Value-Added Pros and Cons: Can Producers Profit from High-

Marette, S., Roosen, J., Blanchemanche, S., \& Feinblatt-Mélèze, E. (2010). Functional

Marketsand Markets (2015). Functional Food Ingredients Market worth $\$ 2.5$ Billion by 2020. available at Markets and Markets http://www.marketsandmarkets.com/PressReleases/functional-foodingredients.asp last access 27/12/2015.

Messina, F., Saba, A., Turrini, A., Raats, M., Lumbers, M., \& Team, F. in L.L., (2008). Older people's perceptions towards conventional and functional yoghurts through the repertory grid method: A cross-country study. British Food Journal, 110, 790-804.

Mullie, P., Godderis, L., \& Clarys, P. (2012). Determinants and nutritional implications associated with low-fat food consumption. Appetite, 58, 34-38.

Niva, M. (2006). Can we predict who adopts health-promoting foods? Users of functional foods in Finland. Scandinavian Journal of Food and Nutrition, 50, 1324.

Nocella, G., \& Kennedy, O. (2012) Food health claims - What consumers understand. Food Policy, 37 (5), 571-580.

Nutraingredients (2009). US leads in healthy food product launches. Available at 
http://www.nutraingredients-usa.com/Markets/US-leads-in-healthy-food-productlaunches Retrieved 09.11.2016.

3 O’Brien, G.M., Stewart-Knox, B.J., McKinley, A., de Almeida, M.D.V., \& Gibney, 4 M.J. (2012). Perceived risk of metabolic syndrome and attitudes towards fat5 modified food concepts among European consumers. Food Quality and $6 \quad$ Preference, 23, 79-85.

7 Øvrum, A., Alfnes, F., Almli, V.L., \& Rickertsen, K. (2012). Health information and diet choices: Results from a cheese experiment. Food Policy, 37, 520-529.

9 Özen, A. E., Pons, A., \& Tur, J.A. (2012). Worldwide consumption of functional foods: a systematic review. Nutrition Reviews, 70, 472-481.

Özen, A. E., Bibiloni, M., Pons, A., \& Tur, J. A. (2014). Consumption of functional foods in Europe; a systematic review. Nutricion Hospitalaria, 29(3), 470-478

Ozer, B.H., \& Kirmaci, H.A. (2010). Functional milks and dairy beverages. International Journal of Dairy Technology, 63, 1-15.

Parmenter, K., \& Wardle, J. (1999). Development of a general Nutrition Knowledge Questionnaire for adults. European Journal of Clinical Nutrition, 53, 293-303.

Peng, Y., West, G.E., \& Wang, C. (2006). Consumer Attitudes and Acceptance of CLA - Enriched Dairy Products. Canadian Journal of Agricultural Economics/Revue canadienned'agroeconomie, 54, 663-684.

Playne, M.J., Bennett, L.E., \& Smithers, G.W. (2003) Functional dairy foods and ingredients. Austalian Journal Dairy Technology, 58, 242-264.

Pliner, P., \& Hobden, K. (1992). Development of a scale to measure the trait of food neophobia in humans. Appetite, 19, 105-120.

Poulsen, C. S., Juhl, H. J., Kristensen, K., Bech, A. C., \& Engelund, E. (1996). Quality guidance and quality formation. Food Quality and Preference, 7, 127-135.

Regulation of European Commission (EU) No 1924/2006 of the European Parliament and of the Council of 20 December 2006 on nutrition and health claims made on foods. 
1 Regulation of European Commission (EU) No 432/2012 of 16 May 2012. Establishing a list of permitted health claims made on foods, other than those referring to the reduction of disease risk and to children's development and health.

4 Research and Markets (2014). Global Functional Food and Nutraceuticals Market (2014 - 2020) - By Type (Foods, Beverages, Supplements); Benefits (Health and

7 Rogers, R.W. (1975). A Protection Motivation Theory of Fear Appeals and Attitude Wellness, Disease Prevention, Fitness, Beauty); Origin \& Ingredient. Change. The Journal of Psychology: Interdisciplinary and Applied, 91 (1), 93114.

Roininen, K., Lähteenmäki, L., \& Tuorila H. (1999). Quantification of consumer attitudes to health and hedonic characteristics of foods. Appetite, 33, 71-88.

Siegrist, M., Stampfli, N., \& Kastenholz, H. (2008). Consumers' willingness to buy functional foods. The influence of carrier, benefit and trust. Appetite, 51, 526529.

Siró, I., Kápolna, E., Kápolna, B., \& Lugasi, A., (2008). Functional food. Product development, marketing and consumer acceptance-A review. Appetite, 51, 456467.

Starling, S., (2014). Functional foods resist recession but failure rate stays high: Analyst. July $7^{\text {th }}$. Available at Nutraingredients.com http://www.nutraingredients.com/Consumer-Trends/Functional-foods-resistrecession-but-failure-rate-stays-high-Analyst Retrieved 09.04.2015.

Stein, A.J., \& Rodríguez-Cerezo, E. (2008). Functional food in the European Union. Technical Report by the Joint Research Centre of the European Commission, EUR 23380 EN. Luxemburg: European Communities.

Urala, N., \& Lähteenmäki, L. (2004). Attitudes behind consumers' willingness to use functional foods. Food Quality and Preference, 15, 793-803.

Urala, N., \& Lähteenmäki, L. (2007). Consumers' changing attitudes towards functional foods. Food Quality and Preference, 18, 1-12.

Valls, J, Pasamontes, N., Pantaleón, A., Vinaixa, S., Vaqué, M., Soler, A., Millán, S., \& Gómez, X., 2013. Prospects of Functional Foods/ Nutraceuticals and Markets. Natural Products, Springer-Verlag Berlin Heidelberg. 
1 Van Kleef, E., van Trijp, H., Luning, P., \& Jongen, W. M. (2002). Consumer-oriented

2 functional food development: how well do functional disciplines reflect the "voice of

3 the consumer'?. Trends in Food Science \& Technology, 13(3), 93-101.

4 Van Kleef, E., van Trijp, H.C.M., \& Luning, P. (2005a). Functional foods: health

5 claim-food product compatibility and the impact of health claim framing on

6 consumer evaluation. Appetite, 44, 299-308.

7 Van Kleef, E., van Trijp, H. C., \& Luning, P. (2005b). Consumer research in the early

8 stages of new product development: a critical review of methods and

9 techniques. Food quality and preference, 16(3), 181-201.

van Herpen, E., van den Broek, E., van Trijp, H. C., \& Yu, T. (2016). Can a virtual supermarket bring realism into the lab? Comparing shopping behavior using virtual and pictorial store representations to behavior in a physical store. Appetite, 107, 196-207.

Verbeke, W. (2005). Consumer acceptance of functional foods: socio-demographic, cognitive and attitudinal determinants. Food Quality and Preference, 16, 45-57.

Viana, J. V., Da Cruz, A. G., Zoellner, S. S., Silva, R., \& Batista, A. L. (2008). Probiotic foods: consumer perception and attitudes. International journal of food science \& technology, 43(9), 1577 - 1580.

Wahba, S. A., Arrafa, A. M., Saleh, N. A., Mekkawy, A. A., \& Ahmed, R. T. (2006). Knowledge, attitudes toward functional foods among adults working in the national research center. Journal of Applied Sciences Research, 2(1), 39-43.

Wardle, J., Haase, A. M., Steptoe, A., Nillapun, M., Jonwutiwes, K., \& Bellisie, F. (2004). Gender differences in food choice: the contribution of health beliefs and dieting. Annals of Behavioral Medicine, 27(2), 107-116.

Williams, P., Ridges, L., Batterham, M., Ripper, B., \& Hung, M.C. (2008). Australian consumer attitudes to health claim - food product compatibility for functional foods. Food Policy, 33, 640-643.

Zandstra, E., de Graaf, C., \& Van Staveren, W., (2001). Influence of health and taste attitudes on consumption of low- and high-fat foods. Food Quality and Preference, 12, 75-82. 
2 Figure 1. Selection papers process.

Queries used:

1) "cheese" OR "yogurt" OR "butter" OR "milk" OR "spreadable" OR "functional food" AND "consumer";

2) "low fat" OR "light" OR "low salt" OR "vitamin" OR "omega-3" OR "fatty acid" OR "CLA" OR "calcium" OR "antioxidant" OR "probiotic" OR "prebiotic" OR "fibre" OR "functional food" AND "consumer".

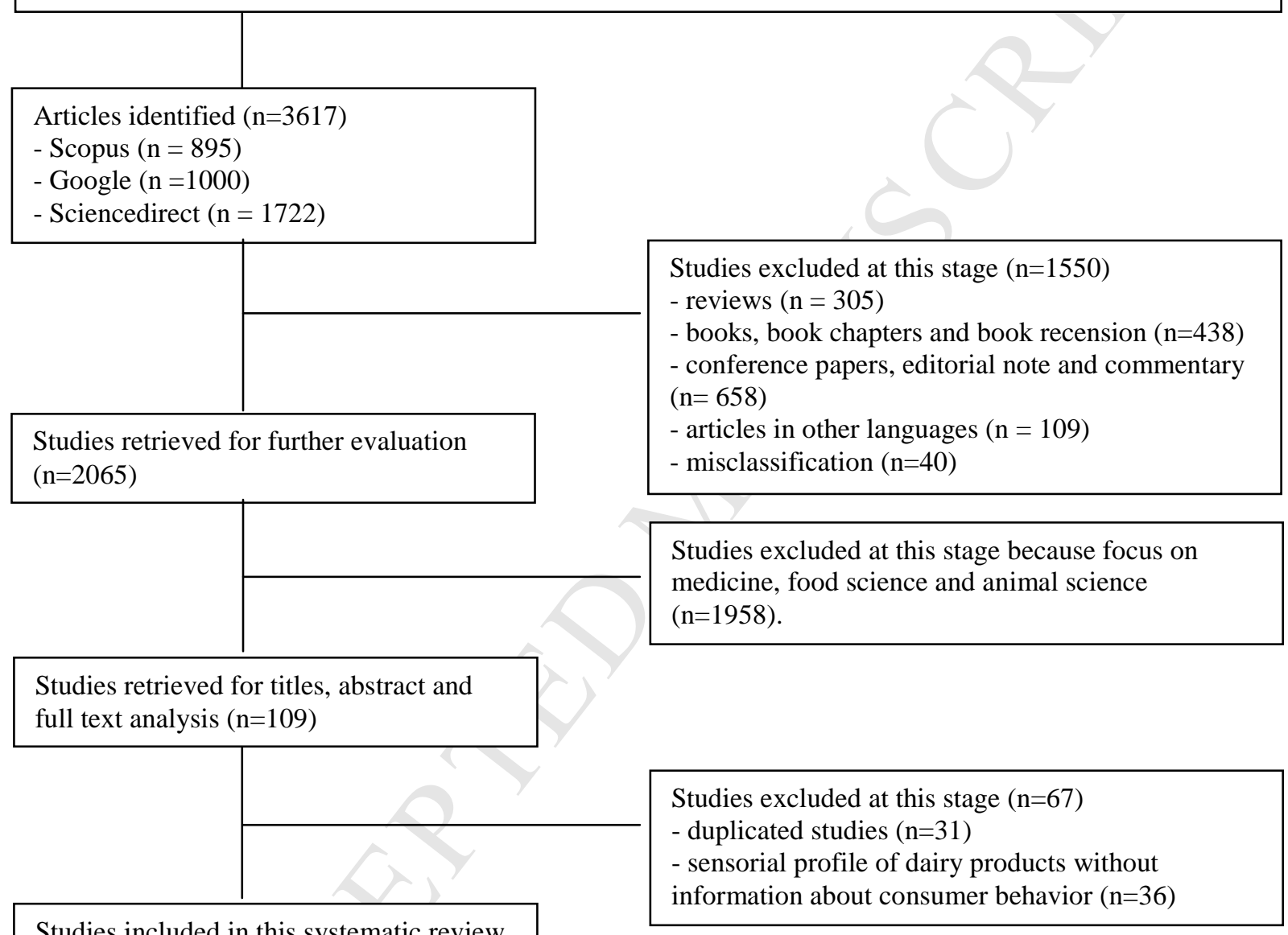

Studies included in this systematic review $(\mathrm{n}=42)$ 
Table 1 . Summary of the studies, quality ranking and research area covered.

\begin{tabular}{|c|c|c|c|c|c|c|}
\hline \multirow[b]{2}{*}{ Study } & \multirow[b]{2}{*}{ Quality } & \multicolumn{5}{|c|}{ Area covered } \\
\hline & & Gender & Age & $\begin{array}{l}\text { Diet-health } \\
\text { knowledge and } \\
\text { lifestyle }\end{array}$ & $\begin{array}{l}\text { Perceived healthiness } \\
\text { and product attributes }\end{array}$ & $\begin{array}{l}\text { Psychological } \\
\text { factors }\end{array}$ \\
\hline Almli et al. (2011) & Medium & & & & & $\mathrm{X}$ \\
\hline Annunziata \& Vecchio (2013) & High & $\mathrm{X}$ & & $\mathrm{X}$ & $\mathrm{X}$ & \\
\hline Ares \& Deliza (2010) & Low & & & & $\mathrm{X}$ & \\
\hline Ares \& Gambaro (2007) & Medium & $\mathrm{X}$ & & & $\mathrm{X}$ & \\
\hline Ares et al.(2008) & Low & & & $\mathrm{X}$ & $\mathrm{X}$ & \\
\hline Ares et al.(2009) & Medium & $\mathrm{X}$ & $\mathrm{X}$ & & $\mathrm{X}$ & \\
\hline Ares et al.(2010a) & Medium & $\mathrm{X}$ & & & $\mathrm{X}$ & \\
\hline Ares et al.(2010b) & Medium & $\mathrm{X}$ & & & $\mathrm{X}$ & \\
\hline Barrena \& Sanchez (2010) & Low & & & $\mathrm{X}$ & $\mathrm{X}$ & $\mathrm{X}$ \\
\hline Barrios et al. (2007) & Low & & & $\mathrm{X}$ & & \\
\hline Bech-Larsen \& Grunert (2002) & High & & & & $\mathrm{X}$ & \\
\hline Bonanno (2012) & High & & $\mathrm{X}$ & & & \\
\hline Chase et al.(2009) & High & & $\mathrm{X}$ & $\mathrm{X}$ & $\mathrm{X}$ & \\
\hline Cox et al. (2007) & High & & & & & $\mathrm{X}$ \\
\hline Cox et al.(2011) & High & $\mathrm{X}$ & & & & \\
\hline de Jong et al. (2003) & High & & $\mathrm{X}$ & $\mathrm{X}$ & & \\
\hline Grunter et al. (2000) & Medium & & & & & \\
\hline Hailu et al. (2009) & Medium & $\mathrm{X}$ & $\mathrm{X}$ & $\mathrm{X}$ & $\mathrm{X}$ & \\
\hline Johansen et al. (2011) & Medium & $\mathrm{X}$ & & & $\mathrm{X}$ & \\
\hline Kahkonen \& Tuorila (1999) & Low & & & & $\mathrm{X}$ & \\
\hline Krutulyte et al. (2008) & High & & & & $\mathrm{X}$ & \\
\hline Krutulyte et al. (2011) & High & & & & $\mathrm{X}$ & \\
\hline Labrecque et al. (2006) & High & & & $\mathrm{X}$ & & $\mathrm{X}$ \\
\hline Lähteenmäki et al.(2010) & High & & & & $\mathrm{X}$ & \\
\hline Landström et al. (2007) & High & $\mathrm{X}$ & $\mathrm{X}$ & $\mathrm{X}$ & & $\mathrm{X}$ \\
\hline Landström et al. (2009) & Low & & & $\mathrm{X}$ & & \\
\hline Marette et al. (2010) & High & & & & $\mathrm{X}$ & \\
\hline Maynard (2005) & Low & & & & $\mathrm{X}$ & \\
\hline Messina et al.(2008) & High & & $\mathrm{X}$ & & $\mathrm{X}$ & \\
\hline Mireaux et al. (2007) & Low & & & & & \\
\hline Mullie et al. (2013) & High & & $\mathrm{X}$ & & & \\
\hline O'Brien et al. (2012) & High & & & & $\mathrm{X}$ & \\
\hline Øvrum et al. (2012) & High & & $\mathrm{X}$ & $\mathrm{X}$ & $\mathrm{X}$ & \\
\hline Peng et al. (2006) & Medium & $\mathrm{X}$ & $\mathrm{X}$ & & $\mathrm{X}$ & \\
\hline Siegrist et al. (2008) & High & $\mathrm{X}$ & & & & $\mathrm{X}$ \\
\hline Urala \& Lähteenmäki (2004) & High & & & & & $\mathrm{X}$ \\
\hline Urala \& Lähteenmäki (2007) & High & $\mathrm{X}$ & $\mathrm{X}$ & & & $\mathrm{X}$ \\
\hline van Kleef et al. (2005a) & High & & & $\mathrm{X}$ & $\mathrm{X}$ & \\
\hline Viana et al., (2008) & Low & & & $\mathrm{X}$ & & \\
\hline Wahba et al. (2006) & Medium & & & $\mathrm{X}$ & & \\
\hline Williams et al. (2008) & Low & & & & $\mathrm{X}$ & \\
\hline Zandstra et al. (2001) & Medium & & & $\mathrm{X}$ & & $\mathrm{X}$ \\
\hline
\end{tabular}


Table A.1. - Study attributes and criteria of the quality assessment tool used in this review

\begin{tabular}{|c|c|c|c|c|}
\hline \multirow{2}{*}{$\begin{array}{c}\text { Studies } \\
\text { attribute }\end{array}$} & \multirow{2}{*}{$\begin{array}{l}\text { Criteria } \\
\text { assessed }\end{array}$} & \multicolumn{3}{|c|}{ Quality rating } \\
\hline & & Low & Medium & High \\
\hline Methodology & $\begin{array}{l}\text { What it is the } \\
\text { methodology } \\
\text { researchers } \\
\text { used in this } \\
\text { study? }\end{array}$ & Qualitative & $\mathrm{n} / \mathrm{a}$ & Quantitative \\
\hline \multirow[t]{2}{*}{ Sample size } & $\begin{array}{l}\text { Is the sample } \\
\text { size adequate? }\end{array}$ & Less than 49 & Between 50 and 500 & Over 500 \\
\hline & $\begin{array}{l}\text { Is the sample } \\
\text { representative } \\
\text { for the } \\
\text { population or } \\
\text { of the group } \\
\text { of interest? }\end{array}$ & No & $\mathrm{n} / \mathrm{a}$ & Yes \\
\hline $\begin{array}{l}\text { Is a } \\
\text { theoretical } \\
\text { model } \\
\text { employed? }\end{array}$ & $\begin{array}{l}\text { Theory driven } \\
\text { results? }\end{array}$ & No & & Yes \\
\hline $\begin{array}{l}\text { Confounders } \\
\text { and bias }\end{array}$ & $\begin{array}{l}\text { Are potential } \\
\text { confounders } \\
\text { minimized? }\end{array}$ & $\begin{array}{l}\text { Confounders or } \\
\text { sample selection not } \\
\text { adequately described. }\end{array}$ & $\begin{array}{l}\text { Confounders } \\
\text { minimized or } \\
\text { explicitly stated. }\end{array}$ & $\begin{array}{l}\text { Confounders } \\
\text { controlled for in } \\
\text { study design or } \\
\text { analysis. }\end{array}$ \\
\hline $\begin{array}{l}\text { Outcome } \\
\text { measurement } \\
?\end{array}$ & $\begin{array}{l}\text { Is the outcome } \\
\text { measure } \\
\text { validated } \\
\text { and/or } \\
\text { objectively } \\
\text { quantifiable? }\end{array}$ & $\begin{array}{l}\text { No, it is not validated } \\
\text { and/or it is not an } \\
\text { objectively quantifiabl } \\
\text { e measure. }\end{array}$ & $\mathrm{n} / \mathrm{a}$ & $\begin{array}{l}\text { Yes, it is a } \\
\text { validated and/or } \\
\text { objectively } \\
\text { quantifiable } \\
\text { measure. }\end{array}$ \\
\hline $\begin{array}{l}\text { Overall } \\
\text { rating }\end{array}$ & & $\begin{array}{l}\text { No or one high } \\
\text { rating (excluded the } \\
\text { case of one high and } \\
\text { two medium) }\end{array}$ & $\begin{array}{l}\text { Two high ratings- } \\
\text { or one high rating } \\
\text { and two medium }\end{array}$ & $\begin{array}{l}\text { Three or more } \\
\text { high ratings }\end{array}$ \\
\hline
\end{tabular}


Table A.2. - Quality assessment table ${ }^{1}$ summarizing studies on consumer acceptance and preference for dairy functional foods.

\begin{tabular}{|c|c|c|c|c|c|c|c|}
\hline Author, date & $\begin{array}{l}\text { What it is the } \\
\text { methodology } \\
\text { researchers used } \\
\text { in this study? }\end{array}$ & $\begin{array}{l}\text { Sample } \\
\text { size } \\
\text { adequate? }\end{array}$ & $\begin{array}{l}\text { Is sample } \\
\text { representativ } \\
\text { e? }\end{array}$ & $\begin{array}{l}\text { Theory driven } \\
\text { results? }\end{array}$ & $\begin{array}{l}\text { Are potential confounders } \\
\text { minimized? }\end{array}$ & $\begin{array}{l}\text { Is the outcome } \\
\text { measure validated } \\
\text { and/or objectively } \\
\text { quantifiable? }\end{array}$ & $\begin{array}{l}\text { Overall } \\
\text { rating }\end{array}$ \\
\hline \multirow[t]{2}{*}{ Almli et al., 2011} & High & Medium & Low & Low & Medium & Low & Medium \\
\hline & $\begin{array}{l}\text { Quantitative } \\
\text { (ANOVA) }\end{array}$ & $\mathrm{N}=239$ & No & No & $\begin{array}{l}\text { Explicitly stated (the samples are } \\
\text { biased towards a good } \\
\text { perceived economic situation for } \\
\text { the household) }\end{array}$ & $\begin{array}{l}\text { No (willingness to buy } \\
\text { scale) }\end{array}$ & \\
\hline \multirow{2}{*}{$\begin{array}{l}\text { Annunziata and Vecchio, } \\
2013\end{array}$} & High & High & High & Low & High & High & High \\
\hline & $\begin{array}{l}\text { Quantitative } \\
\text { (ANOVA and } \\
\text { cluster analysis) }\end{array}$ & $\mathrm{N}=600$ & $\begin{array}{l}\text { Yes } \\
\text { (representati } \\
\text { ve of Italian } \\
\text { population) }\end{array}$ & No & Yes, clear inclusion criteria & $\begin{array}{l}\text { Yes (perceived } \\
\text { healthiness scale) }\end{array}$ & \\
\hline \multirow[t]{2}{*}{ Ares and Delizia, 2010} & Low & Medium & Low & Low & Low & Low & Low \\
\hline & $\begin{array}{l}\text { Qualitative (free } \\
\text { listing and word } \\
\text { association) }\end{array}$ & $\mathrm{N}=100$ & No & No & No (no random sample) & No & \\
\hline \multirow[t]{2}{*}{ Ares and Gambaro, 2007} & High & Medium & Low & Low & Low & High & Medium \\
\hline & $\begin{array}{l}\text { Quantitative } \\
\text { (ANOVA and } \\
\text { cluster analysis) }\end{array}$ & $\mathrm{N}=200$ & No & No & $\begin{array}{l}\text { No (missing considering other } \\
\text { socio demographic variables) }\end{array}$ & $\begin{array}{l}\text { Yes (perceived } \\
\text { healthiness scale) }\end{array}$ & \\
\hline \multirow[t]{2}{*}{ Ares et al., 2010a } & High & Medium & Low & Low & Medium & Low & Medium \\
\hline & $\begin{array}{l}\text { Quantitative } \\
\text { (ANOVA and } \\
\text { cluster analysis) }\end{array}$ & $\mathrm{N}=107$ & No & No & $\begin{array}{l}\text { Explicitly stated (sample } \\
\text { overepresentative of female } \\
\text { consumers) }\end{array}$ & No & \\
\hline \multirow[t]{2}{*}{ Ares et al., 2010b } & High & Medium & Low & Low & Medium & High & Medium \\
\hline & $\begin{array}{l}\text { Quantitative } \\
\text { (ANOVA and } \\
\text { cluster analysis) }\end{array}$ & $\mathrm{N}=103$ & No & No & $\begin{array}{l}\text { Explicitly stated (sample } \\
\text { composed of } \\
\text { typical middle class consumers) }\end{array}$ & Yes (part-worth utility) & \\
\hline
\end{tabular}

Table continues to next page 


\begin{tabular}{|c|c|c|c|c|c|c|c|}
\hline Ares et al., 2008 & $\begin{array}{l}\text { High } \\
\text { Quantitative } \\
\text { (ANOVA and } \\
\text { cluster analysis) }\end{array}$ & $\begin{array}{l}\text { Medium } \\
\mathrm{N}=104\end{array}$ & $\begin{array}{l}\text { Low } \\
\text { No }\end{array}$ & $\begin{array}{l}\text { Low } \\
\text { No }\end{array}$ & $\begin{array}{l}\text { Low } \\
\text { No (modified and not } \\
\text { validated Food nutritional } \\
\text { knowledge questionnaire) }\end{array}$ & $\begin{array}{l}\text { Low } \\
\text { No }\end{array}$ & Low \\
\hline Ares et al., 2009 & $\begin{array}{l}\text { High } \\
\text { Quantitative } \\
\text { (ANOVA and } \\
\text { cluster analysis) }\end{array}$ & $\begin{array}{l}\text { Medium } \\
\mathrm{N}=82\end{array}$ & $\begin{array}{l}\text { Low } \\
\text { No }\end{array}$ & $\begin{array}{l}\text { Low } \\
\text { No }\end{array}$ & $\begin{array}{l}\text { Medium } \\
\text { Explicitly stated (low share } \\
\text { of functional food } \\
\text { consumers compared to } \\
\text { non-consumers) }\end{array}$ & $\begin{array}{l}\text { High } \\
\text { Yes (perceived } \\
\text { healthiness scale) }\end{array}$ & Medium \\
\hline Barrena and Sanchez, 2010 & $\begin{array}{l}\text { Low } \\
\text { Qualitative } \\
\text { (means-end } \\
\text { chain approach) }\end{array}$ & $\begin{array}{l}\text { Medium } \\
\mathrm{N}=60\end{array}$ & $\begin{array}{l}\text { Low } \\
\text { No }\end{array}$ & $\begin{array}{l}\text { High } \\
\text { Yes (empirical } \\
\text { framework built } \\
\text { upon previous } \\
\text { literature) }\end{array}$ & $\begin{array}{l}\text { Low } \\
\text { No (convenience sample) }\end{array}$ & $\begin{array}{l}\text { Low } \\
\text { No }\end{array}$ & Low \\
\hline Barrios et al., 2008 & $\begin{array}{l}\text { Low } \\
\text { Qualitative } \\
\text { (focus group) }\end{array}$ & $\begin{array}{l}\text { Medium } \\
\mathrm{N}=59\end{array}$ & $\begin{array}{l}\text { Low } \\
\text { No }\end{array}$ & $\begin{array}{l}\text { Low } \\
\text { No }\end{array}$ & $\begin{array}{l}\text { High } \\
\text { Yes (clear inclusion } \\
\text { criteria) } \\
\end{array}$ & $\begin{array}{l}\text { Low } \\
\text { No }\end{array}$ & Low \\
\hline $\begin{array}{l}\text { Bech-Larsen and Grunert, } \\
2002\end{array}$ & $\begin{array}{l}\text { High } \\
\text { Quantitative } \\
\text { (ANOVA) } \\
\end{array}$ & $\begin{array}{l}\text { High } \\
\mathrm{N}=1533\end{array}$ & $\begin{array}{l}\text { Low } \\
\text { No }\end{array}$ & $\begin{array}{l}\text { Low } \\
\text { No } y\end{array}$ & $\begin{array}{l}\text { Low } \\
\text { No (sample not adequately } \\
\text { described) }\end{array}$ & $\begin{array}{l}\text { High } \\
\text { Yes (perceived } \\
\text { healthiness scale) }\end{array}$ & High \\
\hline Bonanno, 2010 & $\begin{array}{l}\text { High } \\
\text { Quantitative } \\
\text { (random } \\
\text { coefficients logit } \\
\text { model) } \\
\end{array}$ & $\begin{array}{l}\text { High } \\
\mathrm{N}=4488\end{array}$ & $\begin{array}{l}\text { Low } \\
\text { No }\end{array}$ & $\begin{array}{l}\text { High } \\
\text { Yes } \\
\text { (microeconomic } \\
\text { theory) }\end{array}$ & $\begin{array}{l}\text { High } \\
\text { Yes (consumption data of } \\
\text { real products) }\end{array}$ & $\begin{array}{l}\text { High } \\
\text { Yes (consumer's } \\
\text { utility) }\end{array}$ & High \\
\hline Chase et al., 2009 & $\begin{array}{l}\text { High } \\
\text { Quantitative } \\
\text { (ordered probit } \\
\text { model) }\end{array}$ & $\begin{array}{l}\text { High } \\
\mathrm{N}=7947\end{array}$ & $\begin{array}{l}\text { Low } \\
\text { No }\end{array}$ & $\begin{array}{l}\text { High } \\
\text { Yes } \\
\text { (microeconomic } \\
\text { theory) }\end{array}$ & $\begin{array}{l}\text { High } \\
\text { Yes (consumption data of } \\
\text { real products) }\end{array}$ & $\begin{array}{l}\text { High } \\
\text { Yes (consumer's } \\
\text { utility) }\end{array}$ & High \\
\hline Cox et al., 2007 & $\begin{array}{l}\text { High } \\
\text { Quantitative } \\
\text { (multiple } \\
\text { regression } \\
\text { model) } \\
\end{array}$ & $\begin{array}{l}\text { Medium } \\
\mathrm{N}=220\end{array}$ & $\begin{array}{l}\text { High } \\
\text { Yes (in age, } \\
\text { gender) }\end{array}$ & $\begin{array}{l}\text { High } \\
\text { Yes (Protection } \\
\text { Motivation } \\
\text { Theory) }\end{array}$ & $\begin{array}{l}\text { High } \\
\text { Yes (clear inclusion } \\
\text { criteria) }\end{array}$ & $\begin{array}{l}\text { High } \\
\text { Yes (likelihood to } \\
\text { purchase) }\end{array}$ & High \\
\hline
\end{tabular}

Table continues to next page 


\begin{tabular}{|c|c|c|c|c|c|c|c|}
\hline Cox et al., 2011 & $\begin{array}{l}\text { High } \\
\text { Quantitative } \\
\text { (ANOVA) }\end{array}$ & $\begin{array}{l}\text { Medium } \\
\text { Study } 1 \\
(\mathrm{n}=202) \\
\text { Study } 2 \\
(\mathrm{n}=211)\end{array}$ & $\begin{array}{l}\text { Low } \\
\text { No }\end{array}$ & $\begin{array}{l}\text { High } \\
\text { Yes (Protection } \\
\text { Motivation } \\
\text { Theory) }\end{array}$ & $\begin{array}{l}\text { Medium } \\
\text { Explicitly Stated (sample } \\
\text { generally biased in favour } \\
\text { of acceptance of the GM } \\
\text { technology) }\end{array}$ & $\begin{array}{l}\text { High } \\
\text { Yes (consumer's } \\
\text { utility) }\end{array}$ & High \\
\hline de Jong et al., 2003 & $\begin{array}{l}\text { High } \\
\text { Quantitative } \\
\text { (logistic } \\
\text { regression) }\end{array}$ & $\begin{array}{l}\text { High } \\
\mathrm{N}=1183\end{array}$ & $\begin{array}{l}\text { Low } \\
\text { No }\end{array}$ & $\begin{array}{l}\text { Low } \\
\text { No }\end{array}$ & $\begin{array}{l}\text { Medium } \\
\text { Explicitly Stated (sample } \\
\text { with larger share of female } \\
\text { than male consumers) }\end{array}$ & $\begin{array}{l}\text { High } \\
\text { Yes (probability of } \\
\text { outcome) }\end{array}$ & High \\
\hline Grunert et al., 2000 & High & Medium & Low & Low & Low & High & Medium \\
\hline & $\begin{array}{l}\text { Quantitative } \\
\text { (conjoint Analysis) }\end{array}$ & $\mathrm{N}=426$ & No & No & $\begin{array}{l}\text { No (sample not adequately } \\
\text { described) }\end{array}$ & $\begin{array}{l}\text { Yes ( perceived } \\
\text { healthiness scale) }\end{array}$ & \\
\hline Hailu et al., 2009 & $\begin{array}{l}\text { High } \\
\text { Quantitative } \\
\text { (conjoint analysis } \\
\text { and cluster } \\
\text { analysis) }\end{array}$ & $\begin{array}{l}\text { Medium } \\
\mathrm{N}=267\end{array}$ & $\begin{array}{l}\text { Low } \\
\text { No }\end{array}$ & $\begin{array}{l}\text { Low } \\
\text { No }\end{array}$ & $\begin{array}{l}\text { Medium } \\
\text { Explicitly stated (sample } \\
\text { underrepresentation } \\
\text { of certain groups (e.g., } \\
\text { ethnicity) and } \\
\text { overrepresentation } \\
\text { of others (e.g., high } \\
\text { educated and young } \\
\text { consumers) }\end{array}$ & $\begin{array}{l}\text { High } \\
\text { Yes (consumer's } \\
\text { utility) }\end{array}$ & Medium \\
\hline Johansen et al., 2011 & $\begin{array}{l}\text { High } \\
\text { Quantitative (dual } \\
\text { sorting test) }\end{array}$ & $\begin{array}{l}\text { Medium } \\
\mathrm{N}=370\end{array}$ & $\begin{array}{l}\text { Low } \\
\text { No }\end{array}$ & $\begin{array}{l}\text { Low } \\
\text { No }\end{array}$ & $\begin{array}{l}\text { Low } \\
\text { Explicitly Stated } \\
\text { (University student } \\
\text { sample) }\end{array}$ & $\begin{array}{l}\text { High } \\
\text { Yes (consumer's } \\
\text { utility) }\end{array}$ & Medium \\
\hline $\begin{array}{l}\text { Kahkonen and Tuorila, } \\
1999\end{array}$ & $\begin{array}{l}\text { High } \\
\text { Quantitative } \\
\text { (analysis of } \\
\text { variance) }\end{array}$ & $\begin{array}{l}\text { Medium } \\
\mathrm{N}=253\end{array}$ & Jo & $\begin{array}{l}\text { Low } \\
\text { No }\end{array}$ & $\begin{array}{l}\text { Low } \\
\text { No (Sample not adequately } \\
\text { described and some socio } \\
\text { economic variable missed } \\
\text { in the analysis) }\end{array}$ & $\begin{array}{l}\text { Low } \\
\text { No (pleasantness and } \\
\text { buying } \\
\text { probability) }\end{array}$ & Low \\
\hline Krutulyte et al., 2008 & $\begin{array}{l}\text { High } \\
\text { Quantitative } \\
\text { (quantitative } \\
\text { network } \\
\text { representation) }\end{array}$ & $\begin{array}{l}\text { Low } \\
\mathrm{N}=21\end{array}$ & $\begin{array}{l}\text { Low } \\
\text { No }\end{array}$ & $\begin{array}{l}\text { High } \\
\text { Yes (Health Action } \\
\text { Process Approach) }\end{array}$ & $\begin{array}{l}\text { Low } \\
\text { Unclear } \\
\text { (results probably affected } \\
\text { by the larger share of } \\
\text { young consumers) }\end{array}$ & $\begin{array}{l}\text { High } \\
\text { Yes (behavioural } \\
\text { intentions) }\end{array}$ & High \\
\hline
\end{tabular}

Table continues to next page 


\begin{tabular}{|c|c|c|c|c|c|c|c|}
\hline \multirow[t]{2}{*}{ Krutulyte et al., 2011} & High & High & Low & High & Low & High & High \\
\hline & $\begin{array}{l}\text { Quantitative } \\
\text { (logistic } \\
\text { regression) }\end{array}$ & $\mathrm{N}=959$ & No & $\begin{array}{l}\text { Yes (Ad hoc } \\
\text { conceptual } \\
\text { framework built on } \\
\text { the literature) }\end{array}$ & $\begin{array}{l}\text { Unclear (sample } \\
\text { overapresentative of } \\
\text { female consumers } 75 \% \text { ) }\end{array}$ & Yes (probability) & \\
\hline \multirow[t]{2}{*}{ Labreque et al., 2006} & High & High & Low & Low & Medium & High & High \\
\hline & $\begin{array}{l}\text { Quantitative } \\
\text { (linear regression) }\end{array}$ & $\mathrm{N}=545$ & No & No & $\begin{array}{l}\text { Sampling criteria } \\
\text { sufficiently described }\end{array}$ & $\begin{array}{l}\text { Yes (outcome from } \\
\text { validated scales) }\end{array}$ & \\
\hline \multirow[t]{2}{*}{ Lähteenmäki et al,. 2010} & High & High & Low & Low & Medium & High & High \\
\hline & $\begin{array}{l}\text { Quantitative } \\
\text { (linear regression } \\
\text { and Scheffe test) }\end{array}$ & $\mathrm{N}=4612$ & No & No & $\begin{array}{l}\text { Sampling criteria } \\
\text { sufficiently described }\end{array}$ & $\begin{array}{l}\text { Yes (perceived } \\
\text { healthiness scale) }\end{array}$ & \\
\hline \multirow[t]{2}{*}{ Landström et al., 2007} & High & High & Low & Low & Medium & High & High \\
\hline & $\begin{array}{l}\text { Quantitative (t-test, } \\
\text { principal } \\
\text { component } \\
\text { analysis and } \\
\text { logistic regression) }\end{array}$ & $\mathrm{N}=972$ & No & No & $\begin{array}{l}\text { Explicitly Stated (sample } \\
\text { biased towards consumers } \\
\text { favouring the concept of } \\
\text { functional food) }\end{array}$ & $\begin{array}{l}\text { Yes (outcome from } \\
\text { validated scale) }\end{array}$ & \\
\hline \multirow[t]{2}{*}{ Landström et al., 2009} & Low & Low & Low & Low & Medium & Low & Low \\
\hline & $\begin{array}{l}\text { Qualitative (focus } \\
\text { group) }\end{array}$ & $\mathrm{N}=46$ & No & No & $\begin{array}{l}\text { Sampling criteria } \\
\text { sufficiently described }\end{array}$ & No & \\
\hline Marette et al., 2010 & $\begin{array}{l}\text { High } \\
\text { Quantitative } \\
\text { (censored pooled } \\
\text { regression) } \\
\end{array}$ & $\begin{array}{l}\text { Medium } \\
\mathrm{N}=97\end{array}$ & $\begin{array}{l}\text { High } \\
\text { Yes }\end{array}$ & $\begin{array}{l}\text { High } \\
\text { Yes, experimental } \\
\text { theory design. }\end{array}$ & $\begin{array}{l}\text { High } \\
\text { Clear inclusion criteria and } \\
\text { randomization } \\
\text { experimental design. }\end{array}$ & $\begin{array}{l}\text { High } \\
\text { Yes (willingness to } \\
\text { pay) }\end{array}$ & High \\
\hline \multirow[t]{2}{*}{ Maynard L.J., 2005} & Low & Medium & Low & Low & Low & High & Low \\
\hline & $\begin{array}{l}\text { No (descriptive } \\
\text { statistics) }\end{array}$ & $\mathrm{N}=111$ & No & No & $\begin{array}{l}\text { No (sample not adequately } \\
\text { described) }\end{array}$ & $\begin{array}{l}\text { Yes (willingness to } \\
\text { pay) }\end{array}$ & \\
\hline
\end{tabular}




\begin{tabular}{|c|c|c|c|c|c|c|c|}
\hline \multirow[t]{2}{*}{ Messina et al. 2008} & High & High & Low & Low & High & Low & High \\
\hline & $\begin{array}{l}\text { Quantitative } \\
\text { (repertory grid } \\
\text { method) }\end{array}$ & $\mathrm{N}=768$ & No & No & $\begin{array}{l}\text { Yes (clear inclusion } \\
\text { criteria) }\end{array}$ & No & \\
\hline \multirow[t]{2}{*}{ Mireaux et al., 2007} & High & Medium & Low & Low & Low & Low & Low \\
\hline & $\begin{array}{l}\text { Quantitative } \\
\text { (repertory grid } \\
\text { method) }\end{array}$ & $\mathrm{N}=72$ & No & No & $\begin{array}{l}\text { No (sample not adequately } \\
\text { descripted) }\end{array}$ & No & \\
\hline \multirow[t]{2}{*}{ Mullie et al., 2012} & High & High & High & Low & Medium & High & High \\
\hline & $\begin{array}{l}\text { Quantitative } \\
\text { (regression model) }\end{array}$ & $\mathrm{N}=1852$ & Yes & No & $\begin{array}{l}\text { Sampling criteria } \\
\text { sufficiently described }\end{array}$ & $\begin{array}{l}\text { Yes (consumption } \\
\text { data) }\end{array}$ & \\
\hline \multirow[t]{2}{*}{ Ovrum et al., 2012} & High & Medium & Low & High & Low & High & High \\
\hline & $\begin{array}{l}\text { Quantitative } \\
\text { (random ordered } \\
\text { mixed logit) }\end{array}$ & $\mathrm{N}=408$ & No & $\begin{array}{l}\text { Yes, experimental } \\
\text { theory design }\end{array}$ & $\begin{array}{l}\text { No (internet survey with } \\
\text { no information on how } \\
\text { authors selected the } \\
\text { participants) }\end{array}$ & $\begin{array}{l}\text { Yes (willingness to } \\
\text { pay) }\end{array}$ & \\
\hline O'Brien et al., 2012 & $\begin{array}{l}\text { High } \\
\text { Quantitative (t-test } \\
\text { and principal } \\
\text { component } \\
\text { analysis) }\end{array}$ & $\begin{array}{l}\text { High } \\
\mathrm{N}=5067\end{array}$ & $\begin{array}{l}\text { High } \\
\text { Yes }\end{array}$ & $\begin{array}{l}\text { High } \\
\text { Yes (Health Belief } \\
\text { Model) }\end{array}$ & $\begin{array}{l}\text { Low } \\
\text { Unclear random selection }\end{array}$ & $\begin{array}{l}\text { Low } \\
\text { No }\end{array}$ & High \\
\hline Peng et al., 2006 & $\begin{array}{l}\text { High } \\
\text { Quantitative } \\
\text { (factor analysis } \\
\text { and ordered logit } \\
\text { model) } \\
\end{array}$ & $\begin{array}{l}\text { High } \\
\mathrm{N}=803\end{array}$ & $\begin{array}{l}\text { Low } \\
\text { No }\end{array}$ & $\begin{array}{l}\text { Low } \\
\text { No }\end{array}$ & $\begin{array}{l}\text { Low } \\
\text { Unclear random selection }\end{array}$ & $\begin{array}{l}\text { Low } \\
\text { No (unbalance likely } \\
\text { of buying scale) }\end{array}$ & Medium \\
\hline \multirow[t]{2}{*}{ Siegrist et al., 2008} & High & Medium & Low & High & High & Low & High \\
\hline & $\begin{array}{l}\text { Quantitative } \\
\text { (ANOVA, PCA, } \\
\text { regression) }\end{array}$ & $\mathrm{N}=249$ & No & $\begin{array}{l}\text { Yes (Food } \\
\text { Neophobia scale) }\end{array}$ & Clear inclusion criteria & $\begin{array}{l}\text { No (willingness to buy, } \\
\text { unclear scale and } \\
\text { benefits provided by } \\
\text { carriers) }\end{array}$ & \\
\hline
\end{tabular}




\begin{tabular}{|c|c|c|c|c|c|c|c|}
\hline \multirow{2}{*}{$\begin{array}{l}\text { Urala and Lahateenmaki, } \\
2004\end{array}$} & High & High & Low & High & High & High & High \\
\hline & $\begin{array}{l}\text { Quantitative } \\
\text { (Factor analysis } \\
\text { and ANOVA) }\end{array}$ & $\mathrm{N}=1158$ & No & $\begin{array}{l}\text { Yes (general health } \\
\text { interest and natural } \\
\text { product interest) }\end{array}$ & $\begin{array}{l}\text { Yes (confounder clearly } \\
\text { minimized) }\end{array}$ & $\begin{array}{l}\text { Yes (willingness to } \\
\text { use, 7-points scale) }\end{array}$ & \\
\hline \multirow{2}{*}{$\begin{array}{l}\text { Urala and Lahateenmaki, } \\
2007\end{array}$} & High & High & Low & High & High & High & High \\
\hline & $\begin{array}{l}\text { Quantitative } \\
\text { (Factor analysis } \\
\text { and MANOVA) }\end{array}$ & $\mathrm{N}=2269$ & No & $\begin{array}{l}\text { Yes (general health } \\
\text { interest and natural } \\
\text { product interest) }\end{array}$ & $\begin{array}{l}\text { Yes (confounder clearly } \\
\text { minimized) }\end{array}$ & $\begin{array}{l}\text { Yes (willingness to } \\
\text { buy, 7-points scale) }\end{array}$ & \\
\hline \multirow[t]{2}{*}{ van Kleef et al., 2005} & High & Medium & Low & High & High & High & High \\
\hline & $\begin{array}{l}\text { Quantitative } \\
\text { (Factor Analysis } \\
\text { and ANOVA) }\end{array}$ & $\mathrm{N}=124$ & No & $\begin{array}{l}\text { Yes (experimental } \\
\text { design and testing } \\
\text { specific } \\
\text { hypotheses) }\end{array}$ & Yes (selective sample) & $\begin{array}{l}\text { Yes (intention to buy, } \\
\text { 7-points scale) }\end{array}$ & \\
\hline \multirow[t]{2}{*}{ Viana et al., 2008} & Low & Medium & Low & Low & Low & High & Low \\
\hline & $\begin{array}{l}\text { Qualitative } \\
\text { (descriptive } \\
\text { statistical analysis) }\end{array}$ & $\mathrm{N}=420$ & No & No & $\begin{array}{l}\text { No (knowledge of } \\
\text { probiotic with open-ended } \\
\text { questions) }\end{array}$ & Yes (probability) & \\
\hline \multirow[t]{2}{*}{ Wahba et al., 2006} & Low & High & Low & Low & Low & High & Medium \\
\hline & $\begin{array}{l}\text { Qualitative } \\
\text { (descriptive } \\
\text { statistical analysis) }\end{array}$ & $\mathrm{N}=820$ & No & No & $\begin{array}{l}\text { No (general type ok } \\
\text { knowledge analysed) }\end{array}$ & Yes (probability) & \\
\hline \multirow[t]{2}{*}{ Williams et al., 2008} & High & Medium & Low & Low & Low & Low & Low \\
\hline & $\begin{array}{l}\text { Quantitative } \\
\text { (ANOVA and } \\
\text { Regression } \\
\text { analysis) }\end{array}$ & $\mathrm{N}=149$ & No & No & No (not a random sample) & $\begin{array}{l}\text { No (information on } \\
\text { scale measures is } \\
\text { missing) }\end{array}$ & \\
\hline \multirow[t]{2}{*}{ Zandstra et al., 2001} & High & Medium & Low & High & Low & High & High \\
\hline & $\begin{array}{l}\text { Quantitative } \\
\text { (ANOVA) }\end{array}$ & $\mathrm{N}=132$ & No & $\begin{array}{l}\text { Yes (validated } \\
\text { health and taste } \\
\text { attitudes scales) }\end{array}$ & No (not a random sample) & $\begin{array}{l}\text { Yes (total dietary } \\
\text { behaviour) }\end{array}$ & \\
\hline
\end{tabular}




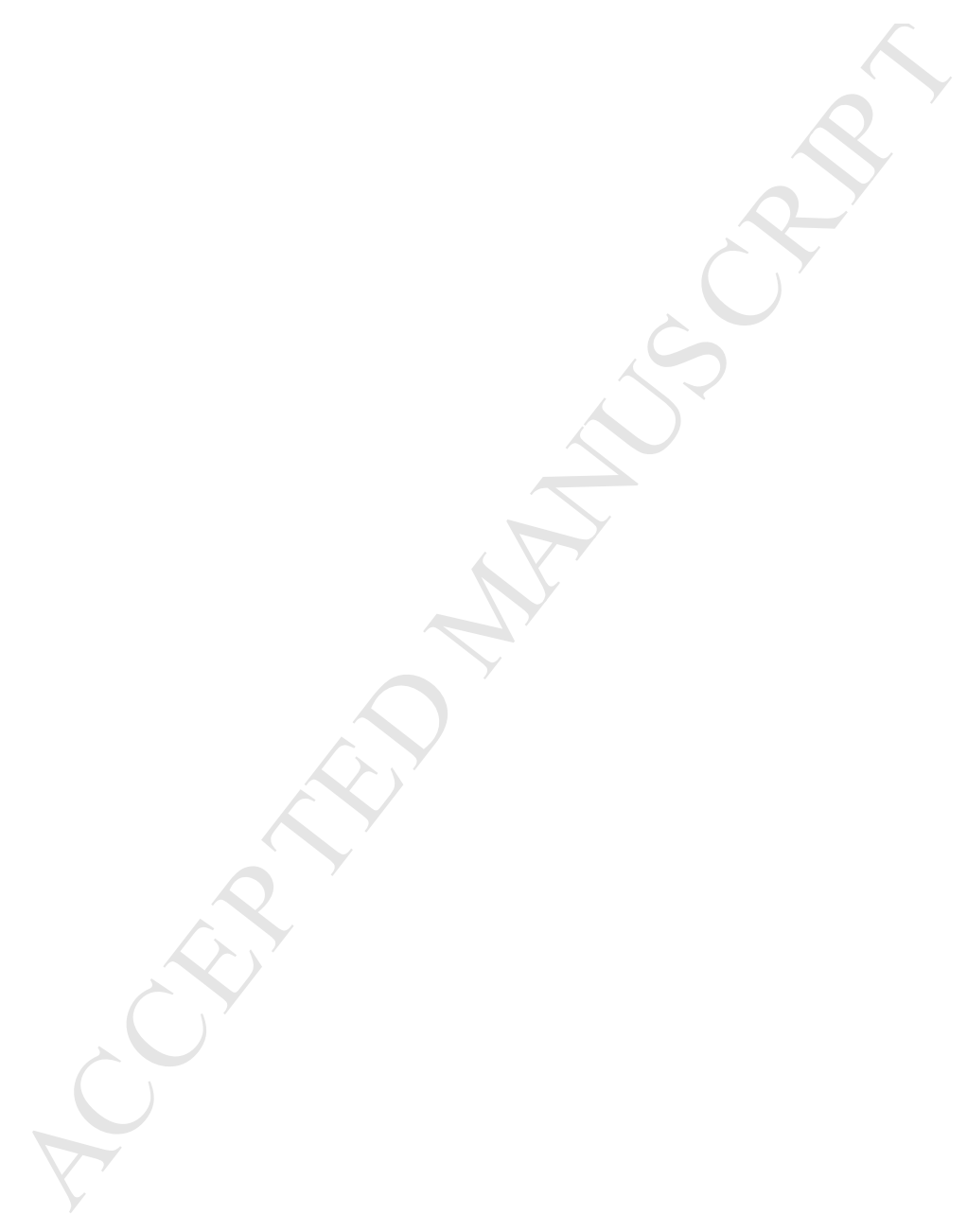




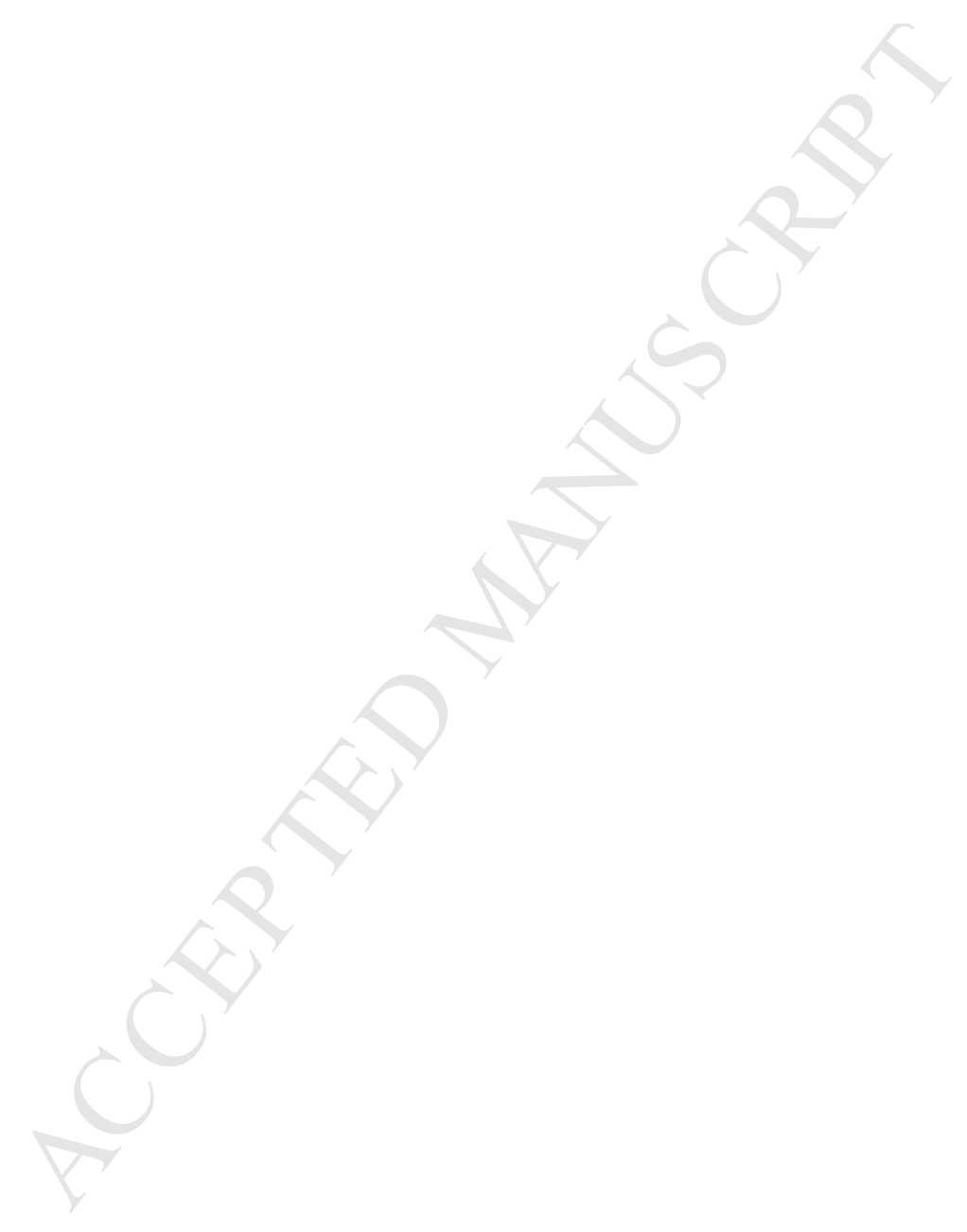

